\title{
A review on recent development of cooling technologies for photovoltaic modules
}

\author{
Zhang Chunxiao ${ }^{1}$, Shen $_{\text {Chao }}^{1 *}$, Wei Shen ${ }^{2}$, Wang Yuan ${ }^{1}$, Lv Guoquan ${ }^{1}$, Sun Cheng $^{1 *}$ \\ ${ }^{1}$ School of Architecture, Harbin Institute of Technology, Key Laboratory of Cold Region Urban and \\ Rural Human Settlement Environment Science and Technology, Ministry of Industry and Information \\ Technology, Harbin 150090, China \\ ${ }^{2}$ The Bartlett School of Construction and Project Management, University College London (UCL), \\ London, WC1E 7HB, UK
}

\begin{abstract}
When converting solar energy to electricity, a big proportion of energy is not converted for electricity but for heating PV cells, resulting in increased cell temperature and reduced electrical efficiency. Many cooling technologies have been developed and used for PV modules to lower cell temperature and boost electric energy yield. However, little crucial review work was proposed to comment cooling technologies for PV modules. Therefore, this paper has provided a thorough review of the up-to-date development of existing cooling technologies for PV modules and given appropriate comments, comparisons and discussions. According to the ways or principles of cooling, existing cooling technologies have been classified as fluid medium cooling (air cooling, water cooling and nanofluids cooling), optimizing structural configuration cooling and phase change materials cooling. Potential influential factors and sub-methods were collected from the review work, and their contributions and impact have been discussed to guide future studies. Although most cooling technologies reviewed in this paper are matured, there are still problems need to be solved, such as the choice of cooling fluid and its usability for specific regions, the fouling accumulation and cleaning of enhanced heat exchangers with complex structures, the balance between cooling cost and net efficiency of PV modules, the cooling of circulating water in tropical areas and the freezing of circulating water in cold areas. To be advocated, due to efficient heat transfer and spectral filter characters, nanofluids can promote the effective matching of solar energy at both spectral and spatial scales to achieve orderly energy utilization.
\end{abstract}

Keywords: Solar energy, PV modules, Cooling technologies, Nanoparticles, Phase change materials 


\section{Introduction}

Solar energy has many advantages, such as large reservation, wide distribution, pollution-free and sustainable. Therefore, it has been used in many countries as a major type of clean energy [1] to deal with the current energy crisis [2]. In real applications, solar energy is mainly collected by either solar photovoltaic (PV) power generation $[3,4]$ or heat collection $[5,6]$. PV cells can convert low-grade solar radiation into high-grade electricity through photoelectric conversion, with no pollutant emissions and additional energy to run the system, hence having high application potentials. According to the “Renewables Energy 2018 - Global Status Report" [7], as shown in Fig. 1, the use of PV cells increased significantly between 2007 and 2017 in the market of renewable energy in many countries and regions, with a total global capacity reached 402GW in 2017.

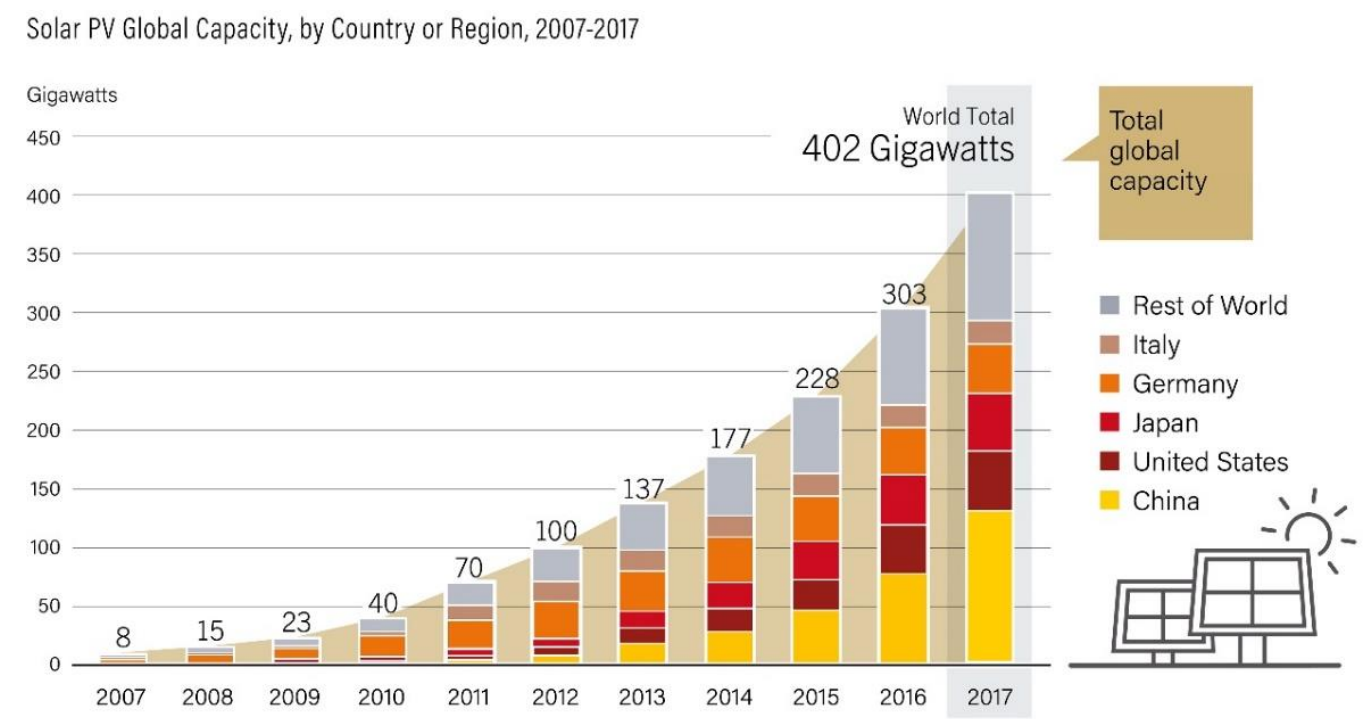

\section{REN21 RENEWABLES 2018 GLOBAL STATUS REPORT}

Fig. 1 Development of global solar PV capacity [7]

PV power generation, however, still has some major issues in real applications. Their characteristics are highly dependent on the physical properties of semiconductor materials, with many influential factors, such as cell temperature [8], dust accumulation [9, 10], inverters and control systems [11], in which cell temperature has the most direct impact on the efficiency of PV cells. Existing literatures have demonstrated that the efficiency of PV cells would decrease by $0.4 \%-0.5 \%$ with $1{ }^{\circ} \mathrm{C}$ increase of cell temperature $[12,13]$. Therefore, to achieve high PV efficiency, it is necessary to apply efficient cooling measures for PV modules to keep the cell temperature at appropriate levels. However, few crucial researches were proposed to compare, review and discuss comprehensive cooling technologies for PV 
modules. This paper is based on a thorough review of recent development of cooling technologies for PV modules with appropriate discussions. The remaining part of the paper still contains six sections. Section 2 explained photoelectric effect and operation characteristics of solar cells. The following three sections described up-to-date cooling technologies from fluid medium cooling (Section 3), structural configuration design to enhance heat transfer (Section 4) and cooling by phase change materials (Section 5). In Section 6, both advantages and disadvantages of existing cooling technologies were summarized, with some issues proposed for further investigations. Finally, a conclusion of the paper could be found in Section 7.

\section{Photovoltaic Modules}

\subsection{Electricity generation}

It is well known that atoms are composed of nucleus and extranuclear electrons. Quantum mechanics have revealed that extranuclear electrons move in some specific quantized orbits. When electrons collide or receive energy from photons, they will change their original orbits, and sometimes even break away from the atomic nucleus and become free electrons.

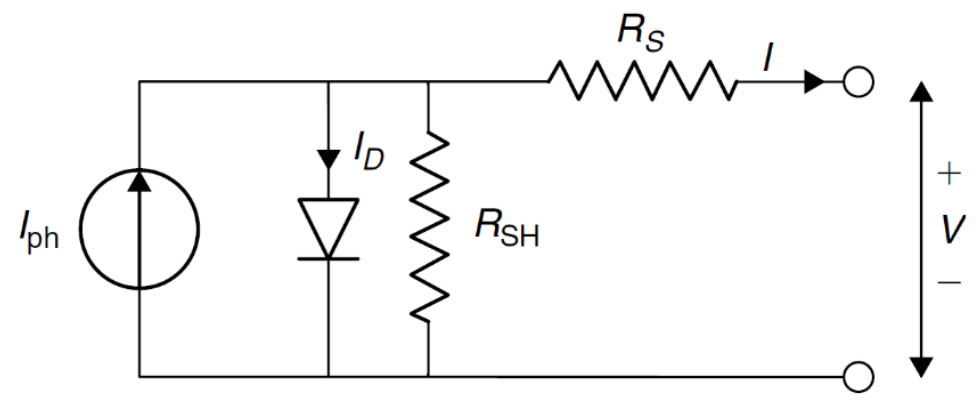

Fig. 2 Equivalent circuit of solar cells [12]

In a PV system, a P-N junction has a positive type semiconductor and a negative type semiconductor and works as the system's power supplier. Due to the difference in the number of holes and free electron density on both P-type and N-type surfaces, an internal electric field can be formed at the P-N junction, directed from the positively charged $\mathrm{N}$ region to the negatively charged $\mathrm{P}$ region [12]. The direction of the electric field is opposite to the direction of the free electron diffusion movement, preventing diffusion. When solar radiation reaches the surface of PV cells (photons strike N-type), electrons will escape from atomic bondage. When the electron movement forming a loop, the PV system will start to generate current, that is, photon current $\boldsymbol{I}_{\boldsymbol{p h}}$. As shown in Fig. 2, since the PV cell is the power source and $\boldsymbol{I}_{\boldsymbol{D}}$ is the diode current, the operating current can be determined by Eq. (1), which 
can be used for either individual PV cells or a PV module with multiple PV cells or PV matrix.

$$
I=I_{P H}-I_{D}-\frac{V+I R_{S}}{R_{S H}}=I_{P H}-I_{0}\left[\exp \left(\frac{e\left(V+I R_{S}\right)}{k T_{C}}\right)-1\right]-\frac{V+I R_{S}}{R_{S H}}
$$

where $\boldsymbol{I}_{p h}$ is photocurrent (A), $\boldsymbol{R}_{S}$ is series resistance ( $\Omega$ ), and $\boldsymbol{R}_{S H}$ is shunt resistance $(\Omega)$.

Generally, the shunt resistance $\boldsymbol{R}_{S H}$ is much bigger than a load resistance, leading to imperceptible electrical currents on $\boldsymbol{R}_{S H}$. While the series resistance $\boldsymbol{R}_{S}$ is much smaller than a load resistance, resulting in less power dissipated internally within the cell. Therefore, without considering these two resistors, Eq. (1) can be simplified as followings,

$$
I=I_{P H}-I_{D}=I_{P H}-I_{0}\left[\exp \left(\frac{e V}{k T_{C}}\right)-1\right]
$$

where $k$ is the Boltzmann constant $\left(1381 \times 10^{-23} \mathrm{~J} / \mathrm{K}\right), \boldsymbol{T}_{\boldsymbol{C}}$ is cell temperature $(\mathrm{K}), \boldsymbol{I}_{\boldsymbol{o}}$ is saturation current (A) dependent on temperature, and $\boldsymbol{V}$ is load voltage (V). When the system does not form a circuit, $\boldsymbol{V}$ is open circuit voltage $V_{O C}(\mathrm{~V})$.

$$
V_{O C}=\frac{k T}{q} \ln \left(\frac{I_{P H}}{I_{0}}+1\right) \approx \frac{k T}{q} \ln \left(\frac{I_{P H}}{I_{0}}\right)
$$

\subsection{Operational characteristics}

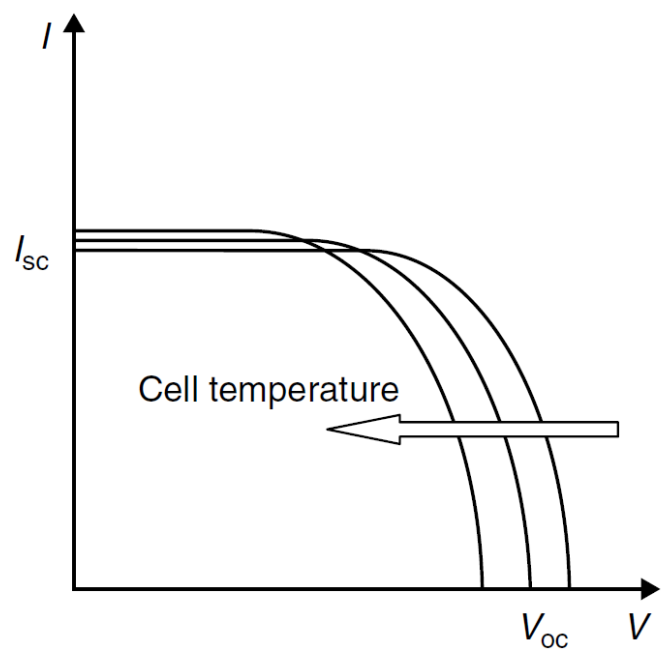

Fig. 3 Effects of cell temperature on characteristic of PV cells [12]

Based on Eqs. (1)-(3), there is a direct correlation between operating current and voltage from the $\boldsymbol{I}-\boldsymbol{V}$ characteristic curve of a PV system, which is related to cell temperature (Fig. 3). Increased cell temperature will result in less short-circuit current changes, larger open-circuit voltage changes, and smaller maximum power point [14]. Existing studies $[15,16]$ have demonstrated that with increased cell temperature, electrical efficiency may decrease by $0.4 \%-0.5 \% /{ }^{\circ} \mathrm{C}$, which is serious for $\mathrm{PV}$ 
utilization. Therefore, many researchers have suggested that PV modules should be properly cooled to improve their efficiency [17-20].

Since silicon cells inside PV modules are fragile, proper measures must be taken to protect them, such as adding EVA and TPT layers to the PV modules. However, these extra layers will increase the cell's thermal insulation, prevent heat release to the ambient environment, and then result in higher cell temperatures. Theoretically, the efficiency of PV cells could go up to $28 \%$ [21], but in reality their efficiency is often less than $17 \%$ [22].

For cooling PV modules to promote their overall efficiency, many methods are available now, and generally they could be classified into three classes, namely, fluid medium cooling, structural configuration design and phase change materials (PCMs) cooling, as depicted in Fig. 4. These technologies, as cooling methods for PV modules, are also called enhance heat transfer methods, which are usually employed in other applications, such as passive buildings, crop drying, solar refrigeration and agricultural greenhouses [23-26]. In the following sections, available cooling technologies within each class would be thoroughly reviewed and discussed. 


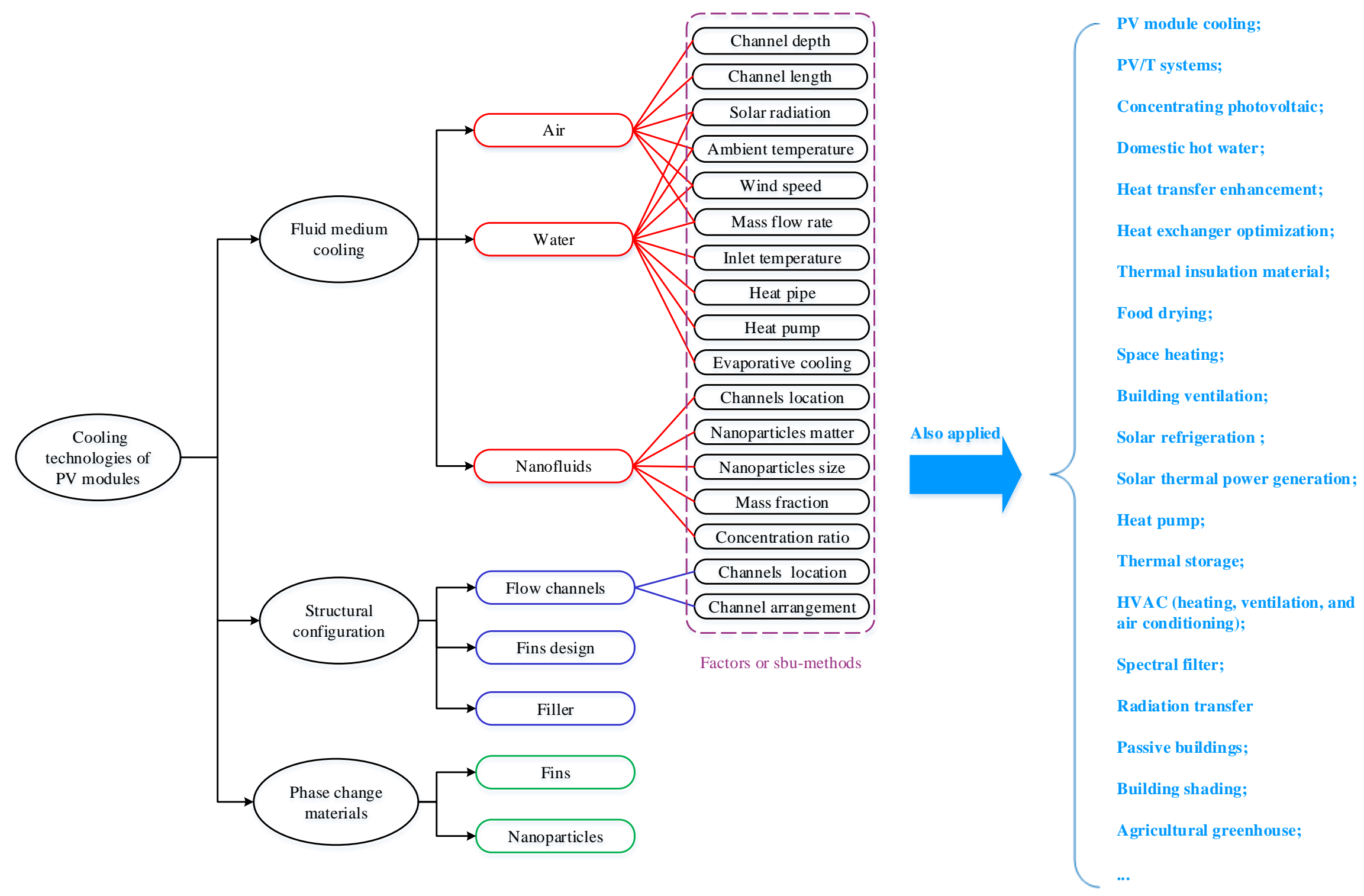




\section{Fluid Medium Cooling}

When solar energy reaches the surfaces of PV modules, some is absorbed and converted into electric energy, and the other, which does not match the spectrum of PV cells, will heat the panels and increase their temperature, hence reducing their efficiency. Fluid medium cooling technique has been widely used to take away redundant heat and remain high electrical efficiency. Fig. 5 has depicted a basic schematic, where it could be seen that in this cooling system fluid channels are attached to either top or back of PV modules and fluid mediums in the duct or the pipe are circulated by either a pump or a fan. This circulation allows heat removal from the surface of PV modules by either heat or mass transfer, so as to cool solar cells and improve their electrical efficiency. Temperature measuring point 1 and 2 measure both inlet and outlet temperatures so the heat removed from the PV modules can be calculated and controlled. The valve is used to regulate the medium flow rate in the system. To enhance energy utilization, this removed heat may also be further used for crop drying [23], building ventilation [24], domestic water $[27,28]$ and low-grade power generation $[29,30]$, through heat exchangers. The way to simultaneously convert solar radiation into both electricity and heat is also named as photovoltaic-thermal systems (PV/T systems), which were originally designed to reduce the temperature of PV modules [18]. Cooling cycle mediums can be either air (Section 3.1), water (Section 3.2) or nanofluids (Section 3.3), and solutions adopting different mediums have been introduced in details in the following three sub-sections.

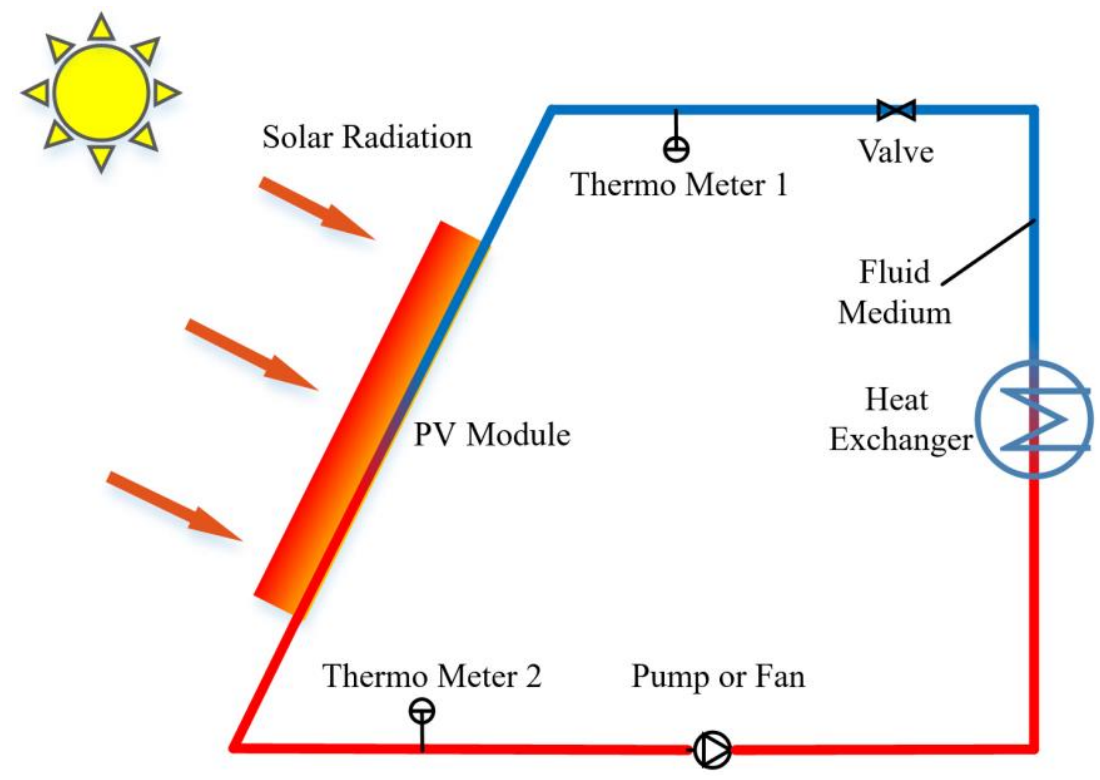

Fig. 5 Principle diagram of fluid medium cooling PV modules 


\subsection{Air-cooling}

Air-cooling PV/T systems use air as the heat transfer medium to take redundant heat away and reduce the temperature of solar cells. Since air has major advantages in terms of both little volumetric change at low-temperature conditions and environment-friendly, it has been widely adopted in real applications, even for severe cold regions [31, 32]. For the air-cooling solution of PV modules, many researchers have investigated potential influential factors on its cooling effect, and these factors can be briefly classified as external environmental factors (solar radiation [33, 34], ambient temperature [33] and wind speed [23]) and design related factors (channel depth, channel length and air mass flow rate [35, 36]).

\subsubsection{External environmental factors}

Solar radiation has been justified as having a negative effect on the cooling effect of PV modules, by investigating its correlation with cell temperature [37, 38]. When excess heat caused by increased solar radiation exceeds the dissipation ability of PV modules themselves, solar cells would be heated to increase their temperature about $1.8^{\circ} \mathrm{C} / 100\left(\mathrm{~W} / \mathrm{m}^{2}\right)$, leading to reduced electrical efficiency of $0.15 \% / 100\left(\mathrm{~W} / \mathrm{m}^{2}\right)$. Sohel et al. [38] found that for an air-cooling PV/T system, increased solar radiation from $100 \mathrm{~W} / \mathrm{m}^{2}$ to $1000 \mathrm{~W} / \mathrm{m}^{2}$ may result in increased cell temperature from $22^{\circ} \mathrm{C}$ to $85^{\circ} \mathrm{C}$ and increased air outlet temperature from $21^{\circ} \mathrm{C}$ to $33^{\circ} \mathrm{C}$. Therefore, higher solar radiation level means more cooling demand for the cooling system $[33,35,39]$. Although solar radiation is unfavorable by air-cooling, it do give more energy to the PV modules [34], which may compensate the decreased electricity generation efficiency caused by higher cell temperature.

Theoretically, when ambient temperature is high, heat exchange between PV modules and air tubes will be weakened due to the smaller temperature difference, hence reducing the cooling efficiency. Some studies have investigated the impact of ambient temperature on the cooling effect of the air-cooling solution [33, 40]. Based on a steady state thermal model, Koech et al. [39] suggested that ambient temperature was disadvantageous to the cooling efficiency of air-cooling solution, leading to reduced electrical efficiency by $0.05 \% /{ }^{\circ} \mathrm{C}$. This conclusion was supported by Sanusi et al. [40], who monitored the operational status of PV modules for three years.

Wind speed may promote the convection heat exchange between PV modules and ambient air, and therefore leads to more heat removed from PV modules. Two existing studies have discussed the 
influence from this factor [38, 41]. Sohel et al. [38] have discovered that the mean temperature of PV modules could be reduced by $5^{\circ} \mathrm{C}$ when increasing wind speed from $5 \mathrm{~m} / \mathrm{s}$ to $20 \mathrm{~m} / \mathrm{s}$, and similar result has been observed by Adeli et al. [41] as well.

\subsubsection{Design related factors}

A few studies have evaluated the correlation between channel length or depth and cell temperature/outlet temperature of air cooling PV/T systems [42, 43], which have been popularly used to represent the cooling effect of air cooling PV/T systems. With constant air mass flow rate, bigger channel depth gives lower flow air velocity, and this will result in higher cell temperature. Tonui et al. [42] have justified that cell temperature could be increased by about $10^{\circ} \mathrm{C}$, when increasing the channel depth from $0.01 \mathrm{~m}$ to $0.50 \mathrm{~m}$. Through a theoretical investigation, Moradi et al. [43] reported that the outlet temperature could be reduced by $2^{\circ} \mathrm{C}-5^{\circ} \mathrm{C}$, by changing channel depth from $0.01 \mathrm{~m}$ to $0.1 \mathrm{~m}$.

When increasing channel length, air will be staying in the channel for a longer time so cannot remove heat efficiently, leading to a lower cooling efficiency [42]. This finding was supported by Koech et al. [39], and they explained that decreased packing factor from increased channel length would lead to increased solar radiation absorbed by the tedlar (the insulation layer [44]). Therefore, more heat would be transferred to PV cells to increase their temperature, and a theoretical investigation suggested that increasing channel length from $0 \mathrm{~m}$ to $6 \mathrm{~m}$ could decrease electrical efficiency from $10.04 \%$ to $9.66 \%$ [39]. Using steady-state simulation, Moradi et al. [43] concluded that increased channel length can increase the outlet temperature but in their study the actual impact on cell temperature has not been discussed.

The impact from air mass flow rate has been investigated in many studies, as it directly determines the temperature difference between PV cells and air in tubes. A higher air mass flow rate will be able to take more heat away from the PV modules to reduce cell temperature [37, 45]. Mojumder et al. [36] have reported that $\mathrm{PV}$ temperature could be reduced from $46^{\circ} \mathrm{C}$ to $39^{\circ} \mathrm{C}$, with increased air mass flow rate from $0.02 \mathrm{~m} / \mathrm{s}$ to $0.14 \mathrm{~m} / \mathrm{s}$, with reduction rate slowing down at higher mass flow rates. Tonui and Tripanagnostopoulos [42] indicated that for a $0.4 \mathrm{~m}^{2}$ area air cooling Si-PV/T system, the outlet temperature could be decreased from $42^{\circ} \mathrm{C}$ to $23^{\circ} \mathrm{C}$ when increasing air mass flow rate from 0 to $0.1 \mathrm{~m} / \mathrm{s}$. The temperature, however, seemed to be stabilized at $23^{\circ} \mathrm{C}$ even when increasing flow rate 
further. This promotion in cooling efficiency gave an increased electrical efficiency from $11 \%$ to $13 \%$.

\subsection{Water-cooling}

The fundamental principle of water-cooling is the same as that of air-cooling, except using water as the heat transfer medium. Comparing to air-cooling PV/T systems, water-cooling PV/T systems are advantageous in terms of cooling efficiency, mainly attributed to the higher thermal conductivity and specific heat capacity of water, leading to more heat carriable per unit mass of water [46]. An existing study [47] has proposed that the thermal efficiency of air-cooling PV/T systems was generally between $30 \%$ and 50\%, while water-cooling PV/T systems could achieve thermal efficiency between $50 \%$ and $70 \%$, indicating more heat to be removable from the PV modules to reduce cell temperature. The factors affecting cell temperature of water-cooling mainly consist of external environmental factors (solar radiation, ambient temperature and wind speed) [48-51], design related factors (inlet water temperature and water mass flow rate) $[49,52,53]$, water evaporative cooling $[54,55]$ and auxiliary technologies (heat pump and heat pipe) [56-58].

\subsubsection{External environmental factors}

Many studies have discussed the factor of solar radiation and got general conclusion. When solar radiation is high, more heat is collected to increase cell temperature, leading to higher cooling demand $[59,60]$. Vittorini et al. [50] found increased cell temperature by $3^{\circ} \mathrm{C}, 4.5^{\circ} \mathrm{C}, 7^{\circ} \mathrm{C}$ and $11^{\circ} \mathrm{C}$ when increasing solar radiation from $250 \mathrm{~W} / \mathrm{m}^{2}$ to $915 \mathrm{~W} / \mathrm{m}^{2}$ for $0.5 \mathrm{~L} / \mathrm{min}, 1.0 \mathrm{~L} / \mathrm{min}, 1.5 \mathrm{~L} / \mathrm{min}$ and $2.0 \mathrm{~L} / \mathrm{min}$ flow rate. Singh et al. [48] also suggested that under high solar radiation heat of PV modules could not be taken away in time, and changing solar radiation from $200 \mathrm{~W} / \mathrm{m}^{2}$ to $1000 \mathrm{~W} / \mathrm{m}^{2}$ led to decreased electrical efficiency from $11.6 \%$ to $11.0 \%$.

There are two existing studies that have investigated the influence of ambient temperature on cooling efficiency of water-cooling solution, with similar reasons as the air-cooling solution. Zhang et al. [49] have reported that for a three-dimensional (3D) physical model of flat-box PV/T collectors the average cell temperature would increase by about $2^{\circ} \mathrm{C}$ when changing ambient temperature from $15^{\circ} \mathrm{C}$ to $30^{\circ} \mathrm{C}$. Using regression models, Vittorini et al. [50] proposed that every $1^{\circ} \mathrm{C}$ increase in ambient temperature might result in an increase of $1.4^{\circ} \mathrm{C}$ in cell temperature.

Similar to air-cooling solution, the influence of wind speed on the cooling effect of water-cooling 

solution has been explored as well in previous studies. Vittorini et al. [50] have suggested that with every $1 \mathrm{~m} / \mathrm{s}$ increase of wind speed the cell temperature would decrease by $3.3^{\circ} \mathrm{C}$, and this conclusion was also supported by Zhang et al. [49].

\subsubsection{Design related factors}

Some studies have explored the influence of inlet water temperature on cooling effect, as it determines the heat transfer effect between the water and solar cells. When inlet water temperature is low, the temperature difference between water and solar cells is high, leading to more heat removable from PV modules and better cooling effect [60, 61]. Zhang et al. [49] have revealed that when decreasing the inlet temperature from $35^{\circ} \mathrm{C}$ to $15^{\circ} \mathrm{C}$, cell temperature could be lowered by up to $9^{\circ} \mathrm{C}$.

Water mass flow rate has been investigated as a factor as well in many studies $[48,53,60]$, with similar reasons as air-cooling solution. Fudholi et al. [52] carried out experiments on a water-cooling PV/T system with varying water mass flow rate from $0.011 \mathrm{~kg} / \mathrm{s}$ to $0.041 \mathrm{~kg} / \mathrm{s}$ and reduced PV temperatures of $2.36^{\circ} \mathrm{C}, 3.08^{\circ} \mathrm{C}, 3.20^{\circ} \mathrm{C}$ and $3.51^{\circ} \mathrm{C}$ were observed under solar radiations of $500 \mathrm{~W} / \mathrm{m}^{2}, 600 \mathrm{~W} / \mathrm{m}^{2}$, $700 \mathrm{~W} / \mathrm{m}^{2}$ and $800 \mathrm{~W} / \mathrm{m}^{2}$, respectively.

\subsubsection{Water evaporative cooling}

When water is transferred from liquid state to gas state, it absorbs great amount of heat, and this, water evaporative cooling, can be used to improve the cooling effect of water-cooling solution [62-64]. Krauter [54] has developed a cooling system flowing water over the module front surface to cool PV panels, as shown in Fig. 6. In this system, the water evaporates at the front surface and takes away significant amount of heat, leading to cell temperature decreased by $22^{\circ} \mathrm{C}$ comparing to conventional PV modules. Abdolzadeh and Ameri [55] have investigated the cooling effect of PV water pumping systems by spraying water over the front of photovoltaic cells. Using this system, the average cell temperature was controlled to be lower than $23^{\circ} \mathrm{C}$, ultimately leading to mean PV efficiency increased from $9.26 \%$ to $12.35 \%$, and this cannot be achieved by the same system without water spray. The performance of amorphous silicon thin PVs with and without water flow has been investigated by Gaur and Tiwari [63], with similar results as Abdolzadeh [55] obtained. 

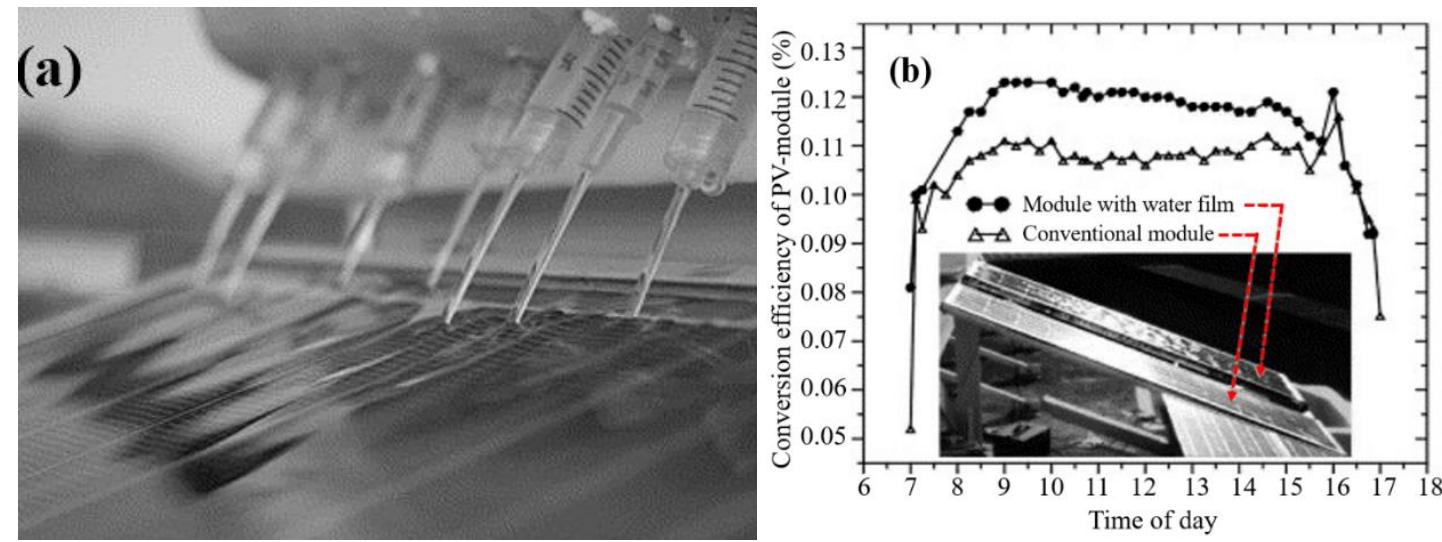

Fig. 6 (a) Water film on the PV module by a line of nozzles (b) Comparison of photovoltaic conversion efficiencies of two PV-modules [54]

\subsubsection{Jet impingement cooling}

Jet impingement cooling, a favorable method to boost PV modules harvest, has been demonstrated by many studies [65-68]. According to the field synergy theory, a 180 degrees synergy will form between the jet direction perpendicular to the PV module and the temperature gradient direction of PV modules to achieve the optimal heat transfer effect. At the same time, jet impingement will also create a stagnation zone under the jet, which can take a lot of heat away and realize the cooling of PV modules. Bahaidarah [69] experimentally investigated the performance of jet impingement cooling used in PV modules in the Middle East, and revealed that cell temperature with jet impingement cooling decreased by $33.1^{\circ} \mathrm{C}$ in June and $16.6^{\circ} \mathrm{C}$ in December compared with the uncooled system. However, the limited impact area limits the cooling effect of the PV module, since the heat transfer coefficient rapidly reduces with the increased distance from the jet inlet. To achieve uniform cooling, some researches have proposed multiple injection ports or arrays of jet improvement to maximize the cooling of PV modules [65, 66]. Awad et al. [65] proposed a novel micro jet impingement integrated with mini-channel to cool a concentrated PV system, and results indicated that cell temperatures with micro jet impingement integrated with mini-channel were $87^{\circ} \mathrm{C}$, cell temperatures with only mini-channel were $104^{\circ} \mathrm{C}$ and cell temperatures without a heat spreader were $108.7^{\circ} \mathrm{C}$ respectively.

\subsubsection{Auxiliary technologies}

In practice, the water-cooling technology is often used with some auxiliary technologies, including heat pump and heat pipe technologies, to maintain low cell temperature. Solar assisted heat pumps combine $\mathrm{PV} / \mathrm{T}$ systems and heat pumps, with the PV/T system working as an evaporator of the heat pump to remove waste heat from PV modules. Since this solution adopts lower temperature for circulating water 
in pipeline comparing to traditional PV/T systems, higher temperature difference between water and

161 PV modules would lead to more heat taken away and reduced cell temperature [70, 71]. Fang et al. [56]

162 experimentally justified that the temperature of conventional PV modules gradually increased from

$16352^{\circ} \mathrm{C}$ to $62^{\circ} \mathrm{C}$ and then dropped to $53^{\circ} \mathrm{C}$ within 120 min due to ambient air flow. However, the temperature of $\mathrm{PV} / \mathrm{T}$ evaporators rapidly decreased from $52^{\circ} \mathrm{C}$ to $9^{\circ} \mathrm{C}$ within $10 \mathrm{~min}$ only and then maintained between $8^{\circ} \mathrm{C}$ and $9^{\circ} \mathrm{C}$ under steady operational conditions.

Heat pipes make full use of the principle of heat conduction and rapid heat transfer property of phase change medium $[72,73]$, and has high heat transfer coefficient to reduce the temperature of PV cells. Some researchers have investigated the performance of cooling PV/T systems assisted by heat pipes [74, 75]. Moradgholi et al. [57] reported that the temperature of PV panels dropped by up to $15^{\circ} \mathrm{C}$, leading to a lower cell temperature. Additionally, they also suggested that comparing to conventional PV panels, the ones with heat pipes could produce more electricity, i.e. $0.72 \%$ more in spring and 0.88\% more in summer, respectively, with similar findings obtained by Qu et al. [76] and Wang et al. [77].

\subsection{Nanofluids-cooling}

Nanofluid is a suspended fluid mixing nanoparticle with water or organic solvent. It can be used as coolant and optical filter for PV panels, owing to their nano-size effect giving high thermal conductivity and characteristic of spectrum absorption [78-80]. solar cells only respond to specific solar spectrum, and the beam splitting approach has been proposed in recent years to realize maximum utilization of solar radiation [81-83]. Only wavelengths that match solar cells' requirements are directed to PV panels, whereas the rest would be filtered out through nanofluids. Factors affecting the cooling

181 effect of nanofluids could be divided into channel location [84, 85], nanoparticles properties [78, 84, 86, 87] and concentration ratio [79].

\subsubsection{Channel location}

The channel location for nanofluids determines the role of nanofluids and then affects their cooling effect to PV modules. When the channel is under PV cells, nanofluids is used as coolant, and can efficiently remove excess heat and cool PV cells, often used in concentrated photovoltaic systems with higher cell temperature. Some researchers have discussed the impact of heat transfer characteristic of nanofluids on the cooling effect to PV cells [78, 84]. He et al. [86] experimentally discovered that the 

one day due to more heat carried away by nanofluid. Karami and Rahimi [84] revealed that the cell temperature with $0.01 \%$ wt boehmite nanofluid was $3^{\circ} \mathrm{C}-5^{\circ} \mathrm{C}$ lower than that with water. In a similar study, Sardarabadi et al. [78] presented that the mean cell temperature of a silica/water nanofluid (1wt\%) PV/T system was $14^{\circ} \mathrm{C}$ lower than a traditional PV module.

194 When the channel is located above PV cells, nanofluids is used as both spectral filters and coolant thanks to the radiative absorption characteristic of particulate matters [88-90]. Nanofluids can absorb part of solar spectrum and remove corresponding energy involved. At the same time, as one type of cooling fluid, nanofluids can take away excessive heat from PV cells and reduce cell temperature to

198 improve cooling effect. Zhao et al. [85] theoretically investigated cell temperature variation of a double-pass PV/T solar collector with the same nanofluid. Results revealed that the cell temperature with nanofluid was lower than that of traditional water PV/T systems, and could maintain $32^{\circ} \mathrm{C}$ without regulating mass flow rate. Cui and Zhu [91] suggested that optical nanofluid needs to work as spectral filters, emphasize optical properties, but thermal nanofluid mainly focused on heat transfer properties to remove excessive heat. For example, increased mass fraction or volume fraction would reduce the transmittance of solar radiation leading to better cooling effect and lower output, but boost heat transfer enhancement. Therefore, Hassani et al. [79] designed separate channels with two different types of nanofluids to optimize optical and thermal properties, respectively, as shown in Fig. 7. The first channel was located above PV cells, containing optical nanofluid, acting as an optical filter, and the second channel was located below PV cells, containing thermal nanofluid to remove redundant heat from the back of PV cells. The study has justified a higher cooling efficiency from separate channels comparing to that from double-pass channels, due to the complementation between optical nanofluid and thermal nanofluid to achieve decreased cell temperature and boosted photoelectric converting. 

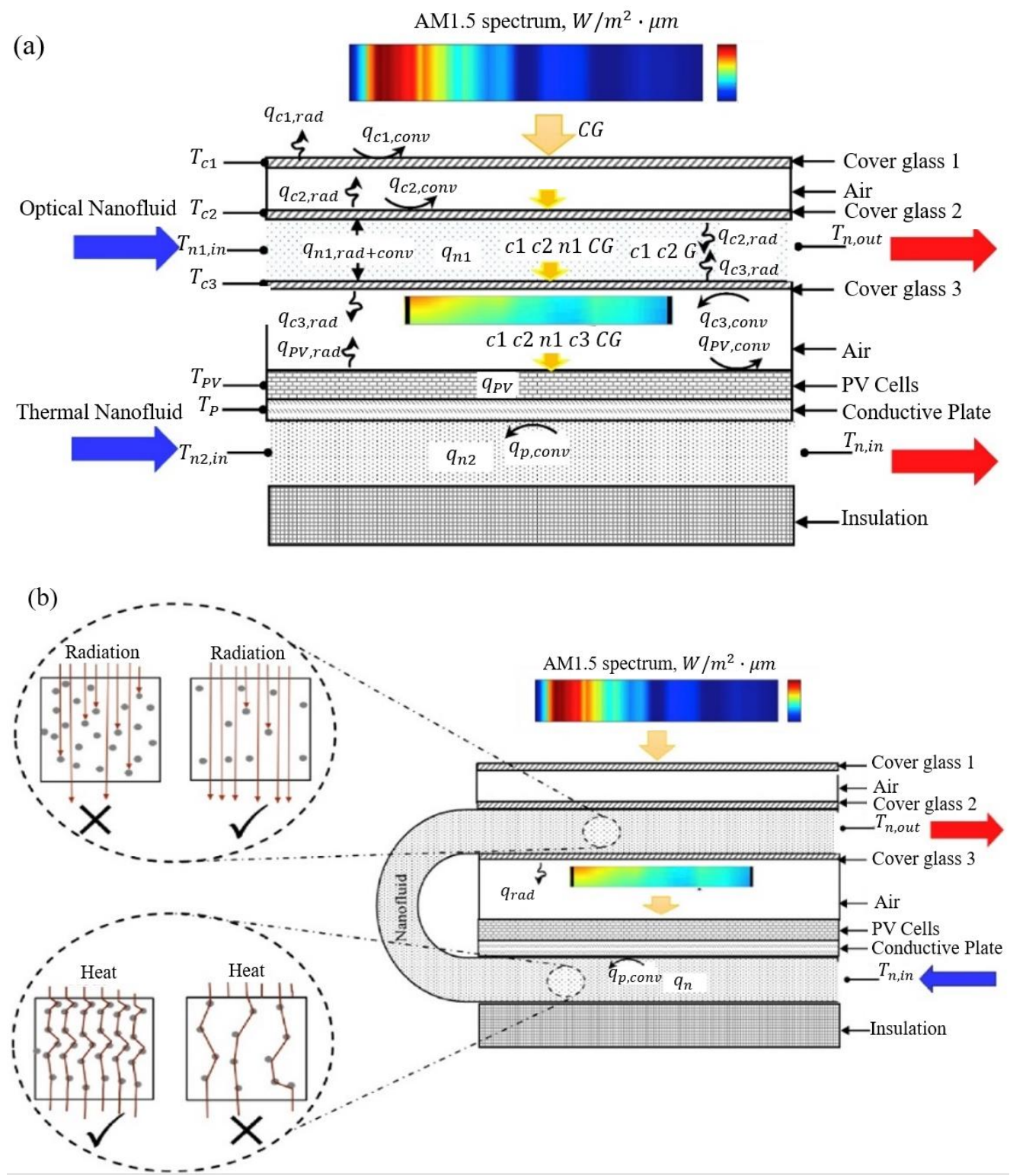

214 Fig. 7 A schematic diagram of a PV/T system; (a) separate channels (b) double-pass channels [79]

\subsubsection{Nanoparticles properties}

216 Nanoparticle matter is a key influential factor on heat transfer efficiency and therefore affects the 217 cooling efficiency to PV modules. Popular particle matters include metal [92, 93], metallic oxide [94, $21895]$ and other compounds [80], which increase heat transfer coefficient between $16.3 \%-47.0 \%[93,96]$ 219 than air or pure water. Khanafer and Vafai [97] have reviewed the thermal conductivity of metallic and non-metallic nanofluids enhancements, and indicated that the thermal conductivity of metallic oxide nanofluids was greater than that of non-metallic nanofluids, and the thermal conductivity of ethylene glycol as solvent nanofluids was much superior to that of water.

223 Nanoparticle size is also a factor affecting nanofluids' outlet temperature and transmittance of solar 
radiation, and has been investigated in some studies [98]. When nanofluid is used as cooling fluid only, increased nanoparticle size will decrease the surface area to volume rate, leading to decreased interfacial heat-transfer coefficient and hence poor cooling effect $[98,99]$. Additionally, increased nanoparticle size will also affect their optical properties, such as increasing reflection and scattering of solar radiation. This change will result in lower outlet temperature of nanofluid and better cooling effect due to less solar radiation received [86, 87]. He et al. [86] presented that the transmittance of $\mathrm{Cu}$-water nanofluid decreased with increased nanoparticle sizes, especially for shortwave radiation $<1 \mu \mathrm{m}$. In a similar work, Du and Tang [87] observed that increased particle size could generate higher extinction coefficient and furthermore suggested that large-sized particles may lead to particle deposition and cause nanofluids unstable. Meanwhile, Hjerrild et al. [100] suggested that particle diameters should be less than 50nm to maintain low energy lost.

Many studies have investigated mass or volume fraction as an influential factor of nanofluids' cooling efficiency $[84,86]$. Increased mass or volume fraction of thermal nanofluids will give bigger effective interfacial heat transfer area, leading to better heat transfer efficiency and cooling effect [78]. A certain mass fraction of nanofluids above the surface of PV cells can absorb specific solar spectrum not useful to PV cells and remove related heat to reduce cell temperature. With increased mass or volume fraction, more solar radiation will be reflected and less will be transmitted, resulting in reduced cell temperature and improved cooling efficiency [20, 87]. Hassani et al. [79] theoretically demonstrated that PV temperature would decrease from $541.0^{\circ} \mathrm{C}$ to $254.8^{\circ} \mathrm{C}$ for $\mathrm{GaAs}$ cells and from $298.2^{\circ} \mathrm{C}$ to $159.3^{\circ} \mathrm{C}$ for Si cells when increasing volume fraction from $0.001 \%$ to $1.5 \%$. In addition, He et al. [86] have discovered increased nanofluid temperature up to $25.3 \%$ higher than that of deionized water when the mass fraction was below $0.01 \mathrm{wt} \%$. When increasing mass fraction continuously, (between $0.01 \mathrm{wt} \%$ and $0.2 \mathrm{wt} \%$ ), the nanofluid temperature started to decrease, mainly due to decreased weighting of solar radiation. However, they also presented decreased transmittance and increased extinction coefficient, when increasing mass fraction. Similar results were also presented by Crisostomo et al. [20] and Du et al. [87]. In order to reduce reflected solar radiation, Hjerrild et al. [100] suggested to have volume fraction of nanoparticles less than $0.6 \%$, with optimal fraction dependent on nanoparticles' materials.

\subsubsection{Concentration ratio}

Concentration ratio is the ratio of solar irradiation gathered per unit area to its incident solar radiation, 
and is a basic index for concentrated photovoltaic systems. Some studies have suggested concentration ratio of solar radiation as a key factor affecting nanofluid-cooling [79, 101]. Higher concentration ratio will lead to more energy intake, leading to increased temperature of PV cells and nanofluids, and poor cooling effect. Radwan et al. [101] indicated that with concentration ratio set at 1,10 and 40, the cell temperature reached $30^{\circ} \mathrm{C}, 32^{\circ} \mathrm{C}$ and $40^{\circ} \mathrm{C}$, respectively, resulting in reduced corresponding electrical efficiency to $19.5 \%, 19.3 \%$ and $18.7 \%$. Hassani et al. [79] mentioned that the cell temperature would increase sharply when increasing solar concentration ratio from 1 to 30 , giving decreased electrical efficiency from $10 \%$ to $1 \%$ for Si cells and from $14.3 \%$ to $9.8 \%$ for GaAs cells. In another study, Hassani et al. [102] also discovered that the PV temperature of Ag/water nanofluid increased from $31.5^{\circ} \mathrm{C}$ to $91.5^{\circ} \mathrm{C}$ as solar concentration ratio rose from 1 to 10 , and the electrical efficiency decreased from $8.4 \%$ to $6 \%$ due to higher cell temperature.

\section{Promoting Heat Transfer through Structural Configuration}

Restricted heat transfer area will limit the cooling efficiency of photovoltaic cells. To tackle this issue, many researchers have tried to optimize the structural configurations of PV modules [103-106], mainly through incorporating flow channels (Section 4.1), fins design (Section 4.2) and fillers (Section 4.3).

\subsection{Flow channels}

In order to raise the time fluid medium spending in the channel to achieve better heat transfer between air/water layers and solar cells, existing studies have proposed different types of flow channels to promote the cooling efficiency of PV modules [107-112].

Fluid channels location is one such a factor, representing either below PV modules or above them. The former solution is designed as thin channels to remove waste heat by cooling medium, to reduce cell temperature, while the latter is working as both optical filters and heat removers on account of spectrum absorption characters and heat/mass transfer property of water. Rahimi et al. [110] discovered decreased average cell temperature from $85.25^{\circ} \mathrm{C}$ to $60.00^{\circ} \mathrm{C}$ due to simple air flow cooling under PV panels, with improved solar cell power generation by $12.99 \%$. Singh et al. [111] theoretically compared cooling efficiencies under two cases, namely, Case I (air cooling both above and below the channel) and Case II (air cooling below the channel only), and found that the mean cell temperature of Case I was $27^{\circ} \mathrm{C}$ lower than that of Case II, leading to increased electrical efficiency by $1.7 \%$. Jin et al. [113] experimentally indicated that the cell temperature of PV/T systems with cooling channels below PV 
panels was $13^{\circ} \mathrm{C}-20^{\circ} \mathrm{C}$ lower under different mass flow rates, comparing to those without cooling channels. Additionally, Ooshaksaraei et al. [112] compared four air-cooling bifacial PV/T solar collectors with different flow channels, Model 1 (single channel below PV panels), Model 2 (double-path with parallel flow), Model 3 (double-path with counter flow) and Model 4 (double-pass with returning flow), as depicted in Fig. 8, and discussed their performances using both mathematical models and experimental studies. Study results have revealed that Model 1 had the highest electricity generation, due to its more solar radiation intake and lower cell temperature.

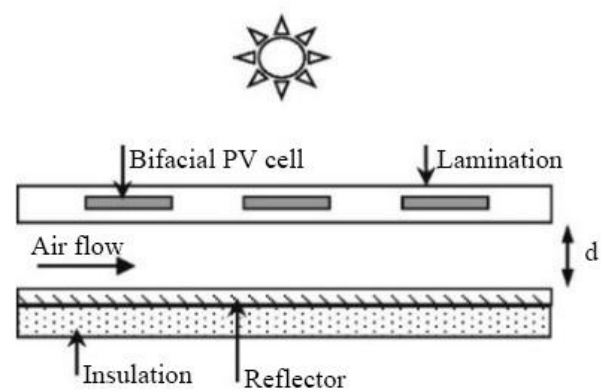

(a)

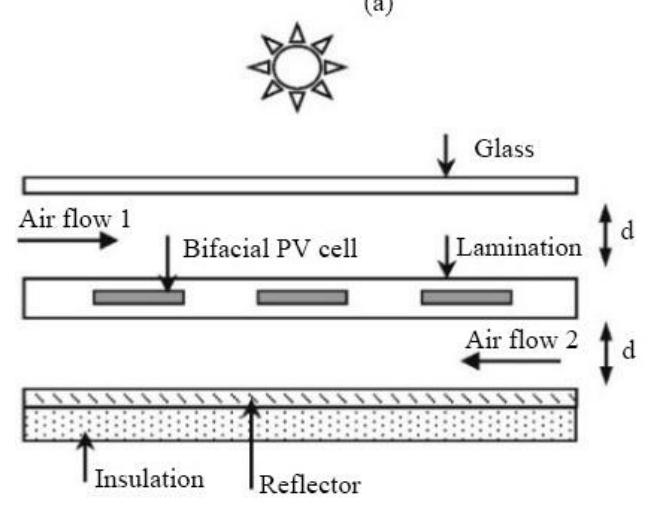

(c)

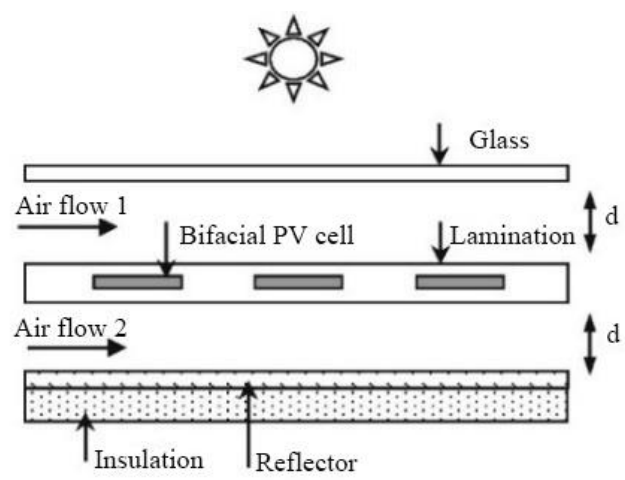

(b)

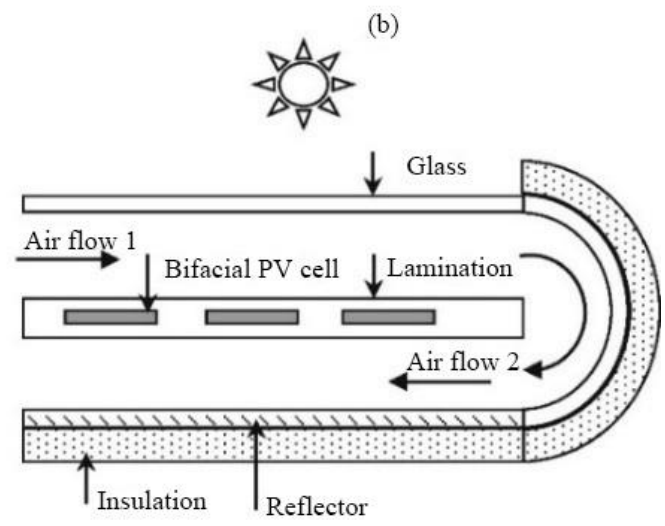

(d)

Fig. 8 Cross-sectional views of four air-based bifacial PV/T solar collectors (1) single-path, (2) double-path with parallel flow, (3) double-path with counter flow, (4) double-pass with returning flow

Flow channels arrangement is also a factor investigated in existing studies. Complex flow state and long residence time of air/water caused by flow channel arrangement may help to promote cooling efficiency [52, 114]. Fudholi et al. [52] have tested the cooling effects of PV/T water collectors with three different arrangements of flow channels (Fig. 9), and indicated that the mean PV temperature of spiral flow channels was $50.20^{\circ} \mathrm{C}$, lower than that of web flow channels $\left(51.44^{\circ} \mathrm{C}\right)$ and direct flow 

average PV temperature of the circular tube channel was $5.5^{\circ} \mathrm{C}$ lower than that of the strip type channel in one day, at $0.06 \mathrm{~kg} / \mathrm{s}$ flow rate.

302
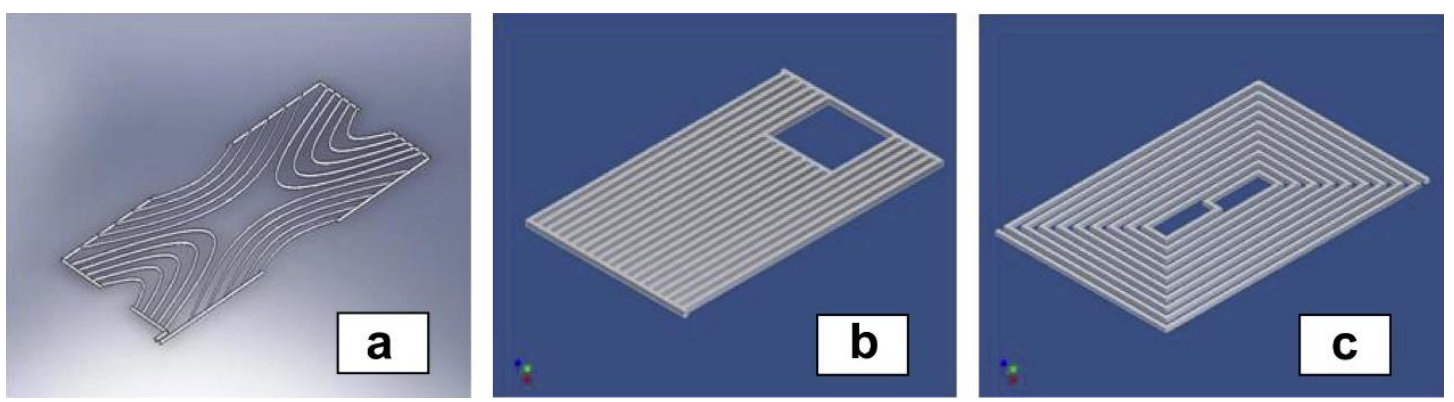

Fig. 9 Three types of absorbers for PV/T water collectors (a) web flow absorber, (b) direct flow absorber and (c) spiral flow absorber [52]

\subsection{Fins design}

Fins are usually used to improve flow state, increase heat transfer area and improve heat transfer effect in heat exchangers. Because of them, fluid flow becomes more turbulent, with increased Reynolds number and heat transfer coefficient $[34,36]$. Additionally, fins can also significantly increase the heat exchange area to enhance heat exchanges [116]. Some researchers have devoted themselves to designing various fins to enhance cooling efficiency for better electricity generation $[52,105,117]$.

Hussain et al. [34] presented an improved design of PV/T solar collectors with hexagonal shape exchangers. With more heat exchange area provided by hexagonal shape fins, lower cell temperature was achieved, resulting in increased electrical efficiency by $0.2 \%$ and improved thermal efficiency between $20 \%-70 \%$ at different air mass flow rates. Xu et al. [117] carried out a contrast experiment from $1^{\text {st }}$ May to $18^{\text {th }}$ May in 2014, and discovered that the mean daily cell temperature of PV/T systems with thin metallic fins was about $1.4^{\circ} \mathrm{C}$ lower than that of conventional PV panels. Mojumder et al. [36] reported PV temperatures with no fins, two fins and four fins as $49.30^{\circ} \mathrm{C}, 46.52^{\circ} \mathrm{C}$ and $43.75^{\circ} \mathrm{C}$, respectively, and suggested the PV/T system with four fins as having the highest electrical efficiency due to its lower cell temperature. Using numerical analysis, Charalambous et al. [114] explored the impact of thickness and tube spacing of fins on systems' cooling efficiency using a steady-state model, and pointed out low-flow rate, less absorber fin thickness, small diameter tubes and tube spacing can optimize electricity yield of PV/T systems. 


\subsection{Fillers}

Fillers in the air duct of PV/T systems can help to promote both thermal conductivity and area of heat transfer to transfer more heat from solar cells to fluid medium, hence giving better cooling efficiency.

Porous materials are commonly used as fillers to enhance heat transfer and improve cooling effect [118], and the cooling principle of porous materials is similar to that of fins. Ahmed et al. [24] applied porous media to cool solar cells, and heat removed by air from the cells was reused to heat buildings. The PV temperatures at $9 \mathrm{am}$ and $2 \mathrm{pm}$ were found to be $16^{\circ} \mathrm{C}$ and $3{ }^{\circ} \mathrm{C}$ lower than that without porous media. Huo et al. [119] have carried out an experimental study to investigate the cooling efficiency of tube plate PV/T systems with iron filings filled. Comparing to that without iron filings filled, the calculated equivalent thermal conductivity of filling iron was $43.91 \mathrm{~W} /(\mathrm{m} \cdot \mathrm{K})$, with reduced cell temperature by $3.5^{\circ} \mathrm{C}$ to $6.5^{\circ} \mathrm{C}$, leading to increased electrical yield by $19.8 \%$.

\section{Cooling by phase change materials}

Phase change materials (PCMs) can absorb great amount of heat when converting phase from solid to liquid. When ambient temperature is high, PCMs start to absorb heat from environment and increase its temperature. When its temperature reaches its melting temperature, PCMs start to absorb a large amount of latent heat, with almost stable temperature. After all PCM changes to liquid, its temperature will start to increase again linearly [120]. Due to the unique thermodynamic characteristics, PCMs can match well with the cooling demand of PV modules to maintain the PV cell temperature in a certain range with small volume change of PCMs [121-123].

The application of PCMs in cooling of PV modules have been investigated in many studies [124-126]. Preet et al. [17] carried out a comparative analysis to investigate the cooling efficiency of three types of PV systems, including convectional PV panels, water-PV/T systems with double absorber plates and water-PV/T systems with paraffin wax. Results from this study revealed that the cell temperature of PV/T-PCM systems was lower than that of the convectional PV panel, and the maximum cell temperature reduction percentages at various flow rates were found to be $49.8 \%$ at $0.013 \mathrm{~kg} / \mathrm{s}, 51.4 \%$ at $0.023 \mathrm{~kg} / \mathrm{s}$ and $53 \%$ at $0.031 \mathrm{~kg} / \mathrm{s}$. Malvi et al. [127] suggested that increasing PCM thickness could help to reduce PV temperature, which gave a maximum increase in electrical yield at $6.5 \%$. However, a maximum depth of $0.03 \mathrm{~m}$ has been found due to the limited thermal conductivity of PCMs, which has 
been justified in other areas as well [128]. Su et al. [129] investigated the influence of PCM layer location on PV cell temperature and proposed that positioning PCM layers over the air flow tunnel could receive better cooling effect than positioning them below the channel, due to lower thermal resistance. Hasan et al. [122] have tested the front surface temperature of BIPV systems with five different types of PCMs, with melting temperatures between $25 \pm 4^{\circ} \mathrm{C}$ and fusion heat between $140 \mathrm{~kJ} / \mathrm{kg}-213 \mathrm{~kJ} / \mathrm{kg}$. From the study, they discovered that the maximum reduction in cell temperature was $18^{\circ} \mathrm{C}$ at $30 \mathrm{~min}$ time and the cell temperature reduction was maintaining at $10^{\circ} \mathrm{C}$ for 5 hours at the $1000 \mathrm{~W} / \mathrm{m}^{2}$ radiation level. Additionally, they also suggested that the system's cooling efficiency was dependent on both PCMs' mass and their thermal conductivities.

Although PCMs' characteristics match well with the cooling requirements of PV cells, the low thermal conductivity of PCMs restricts their ability of removing heat from PV cells and therefore limits their application [130]. Qiu et al. [131, 132] reviewed the recent development of PCMs for solar thermal applications from theory point, and hold that framework structure and nanoparticles integrated in PCMs would contribute to PV cooling. Additionally, if there is too much heat absorbed during the daytime to release during the night time, PCMs would not be able to absorb heat efficiently in the next day [133]. To tackle this issue, some measures, namely, fins attached [134-137] and mixed nanoparticles [138-141], have been explored.

\subsection{Fins attached}

Fins attached on the back of solar cells is beneficial of improving the thermal conductivity of PCMs to help modulate cell temperature and increase electrical efficiency [134, 137]. Huang et al. [135] suggested to use aluminum fins attached by PCMs for PV modules to achieve lower cell temperature.

372 They also indicated smaller fin intervals could help to maintain low PV surface temperature, and at $750 \mathrm{~W} / \mathrm{m}^{2}$ incident solar radiation the surface temperature of PV/PCM with $8 \mathrm{~mm}$ fin spacing would not beyond $28^{\circ} \mathrm{C}$ until $150 \mathrm{~min}$. Atkin and Farid [136] assessed four thermal control techniques (Case A: no thermal control; Case B: with $30 \mathrm{~mm}-\mathrm{PCM}$ infused graphite; Case C: with a finned heat sink; Case D: with a combination of PCM infused graphite and finned heat sink) by both theoretical and experimental investigations. Results demonstrated that the average cell temperature of Case $\mathrm{D}$ was $13^{\circ} \mathrm{C}$ and $10^{\circ} \mathrm{C}$ lower than those of Case A and Case B, respectively, during 240 minutes to 480 minutes for $12 \mathrm{~h}$ simulated daylight irradiation. Abdelrahman et al. [142] carried out an experimental investigation on 
the surface temperature of PV cells with three types of fins, namely, 11 fins (Configuration 1), 18 fins

381 (Configuration 2) and 22 fins (Configuration 3). Comparing to Configurations 1 and 2, Configuration 3

382 gave more significant reduction in surface temperature. Under solar radiation conditions including $383820 \mathrm{~W} / \mathrm{m}^{2}, 514 \mathrm{~W} / \mathrm{m}^{2}$ and $279 \mathrm{~W} / \mathrm{m}^{2}$, the biggest temperature differences between Configuration 3 and 384 Configuration 1 were $13^{\circ} \mathrm{C}, 7^{\circ} \mathrm{C}$ and $6^{\circ} \mathrm{C}$ and those between Configuration 3 and Configuration 2 were $6^{\circ} \mathrm{C}, 5^{\circ} \mathrm{C}$ and $3^{\circ} \mathrm{C}$.

\subsection{Mixed nanoparticles}

387 Except for to integrated fins, researchers also tried to add nanoparticles to PCMs (Nano-PCMs) to increase their thermal conductivity [143-146], including some studies targeting on cooling efficiency of PV modules. Siahkamari et al. [147] have proposed a novel PCM with $\mathrm{CuO}$ nanoparticles to enhance the cooling efficiency of PV modules. From their study, the surface temperatures of PV panels at 65 minutes were found to be $87^{\circ} \mathrm{C}, 77^{\circ} \mathrm{C}, 69^{\circ} \mathrm{C}$ and $62^{\circ} \mathrm{C}$ for PV modules without cooling, with paraffin filled, with sheep fat filled and with sheep fat pulsed $\mathrm{CuO}$ nanoparticles filled. Abdelrahman et al. [142] have compared the thermal behavior in cooling PV modules with and without Nano-PCMs, and discovered that under solar radiations of $820 \mathrm{~W} / \mathrm{m}^{2}, 514 \mathrm{~W} / \mathrm{m}^{2}$ and $279 \mathrm{~W} / \mathrm{m}^{2}$, the surface temperatures of PV panels with nanoparticles $\mathrm{Al}_{2} \mathrm{O}_{3} \mathrm{PCM}$ were $8.7^{\circ} \mathrm{C}, 8.9^{\circ} \mathrm{C}$ and $5.0^{\circ} \mathrm{C}$ lower than those without Nano-PCM, respectively. Additionally, it was also found that increasing nanoparticles concentration can help to decrease surface temperature.

Another copositive PCMs cooling technologies, including phase-change microcapsules [148] and PCM integrated with metal turnings $[149,150]$, were also demonstrated as a positive solution to lower cell temperature. Han et al. [148] numerically investigated the characteristics of heat-storage and the release of phase-change microcapsules, and indicated that the increased cavities number accelerated the rate of heat storage and release, which was a critical method to cool PV modules. Maiti et al. [149] attached the paraffin filled with metal chips on the back of PV modules and set a control group integrated with pure paraffin, and results revealed that 1.55 times of power harvesting of the former compared with the latter due to superior heat conductivity and lower cell temperature.

\section{Discussions}

In today's market, three major active measures are available for cooling PV modules to promote their efficiency in electricity generation, based on different cooling principles. Firstly, fluid medium cooling 
mainly uses circulated fluids, which can be either air, water or nanofluids, to take heat away from PV modules. Secondly, optimizing the structural configuration of PV modules has been adopted to achieve better heat transfer between the PV cells the heat transfer medium, and this was mainly achieved by better design of both flow channels and fins [103-106]. Thirdly, phase change materials are used thanks to their ability of absorb great amount of latent heat when changing phases $[124,126]$.

When using fluid medium cooling technique, active heat exchange by fans or pumps are often employed to maximize its cooling efficiency. Air is pollution-free, cost-free and environment-friendly, and has been widely used for cooling PV modules around the world. However, because its limiting thermal conductivity and specific heat, there are certain of limitations for its application. In many cases, bigger volume of air will be needed to take heat away [46]. Comparing to air, water has a larger specific heat and a better thermal conductivity, hence more advisable for cooling PV modules [47]. However, water is obviously not suitable for regions with ambient temperature lower than $0{ }^{\circ} \mathrm{C}$, when water will change from liquid to solid (ice). Considering the advantages of both air and water, some studies have proposed to use them together [151, 152], either placing both water pipe and air duct above/below PV modules, or placing air duct on the surface of PV panels and water pipe on the back [46]. For tropical regions, air or water with low temperature is often required, and therefore how to achieve a sustained low-temperature circulating water to cool PV modules and reuse waste heat from solar cells are key. For cold regions, since ambient temperatures are often below freezing point, how to solve system breakdown caused by volume change of cooling fluid is extremely important.

For energy utilization, it is important to realize the orderly transformation of solar energy, which is challenging. The residual heat of photovoltaic modules is caused by some spectra that does not required by solar cells $[88,89]$. How this part of energy can be filtered out or used for other purposes before it reaches PV cells is a key topic, and the use of nanofluids creates possibilities of solving this issue. Due to their efficient heat transfer and spectral filter characters $[84,86]$, nanofluids can promote the effective matching of solar energy at both spectral and spatial scales and then achieve orderly energy utilization. On this purpose, nanofluids spectral filters have been developed to optimize efficiency of PV/T systems [153, 154]. When using this solution, since the absorption and reflection of solar radiation by atmospheric molecules $[155,156]$, solar spectrum is dependent on the environment. 
such as reunite and instability are still existing for using nanofluids to cool PV modules and more work is still needed in the future $[97,157]$.

When optimizing structural configuration, there is no need to add extra equipment to achieve cell cooling, hence simplifying PV systems. Although optimizing structure configuration can help to enhance heat transfer efficiency and improve performance of PV/T systems, it needs additional investment and operating costs, especially relevant to system maintenance caused by increased resistance and pressure, as well as deposed fouling [158-160].

When using PCMs to achieve cooling, they can absorb excess heat from solar cells without significantly change their temperature. Furthermore, because PCMs' unique heat absorption characteristics, they can absorb heat during the daytime but release this part of stored heat to environment at night. Low thermal conductivity of PCMs, however, limits their performance in cooling PV modules. Researchers have tried to add fins and nanoparticles to enhance their performance and great improvements have been realized [135, 145]. As PCMs are working as a battery when storing and releasing heat, if the heat stored during the daytime cannot be released effectively during the night, their performance in the next day will be highly reduced. Therefore, use of this method is highly climate dependent.

The advantages and disadvantages of the three cooling methods have been analyzed in detail, but the differences among them need to be analyzed. According to whether the additional energy input is needed, three types of cooling technologies can be divided into active cooling (fluid cooling) and passive cooling (structure optimization and PCM cooling). In other words, active cooling technology relies on forced convection to carry away heat quickly to cool PV modules, while passive cooling method depends on optimizing convection heat transfer coefficient or providing a big temperature difference to achieve cooling. However, many researches combine two or three kinds of cooling technologies to realize the maximum cooling efficiency, and expand its application scope to the greatest extent. Although active cooling technologies may have superior cooling efficiency, most of them remain in experimental or small-scale applications. At the same time, additional energy consumption produced by fans or pumps runs counter to the goal of increasing the amount of electricity generated by PV modules. Therefore, for a wide range of photovoltaic systems, passive cooling should be the preferred technology, due to the advantage of less investment, less maintenance and 
A comparison among the three methods have been made in Table 1, with analysis of potential influential factors. Detailed discussion about these factors on the influence of cooling efficiency has been depicted in Section 3, Section 4 and Section 5. From the cooling effect, some factors contribute positively to the cooling efficiency of PV modules, including wind speed, mass flow rate, inlet temperature, channel location, nanoparticles matter/size, mass or volume fraction, fin design, filler and mixed nanoparticles. They, such as wind speed, mass flow rate, inlet temperature, fins, filler and mixed nanoparticles, enhance the convective heat-transfer coefficient or provide a bigger temperature difference to reduce cell temperature and boost cooling efficiency. However, not all of them help to generate more electricity, because some factors, such as channel location and mass/volume fraction, reduce cell temperature by preventing solar energy receiving solar cells, hence may still lowering energy generation. Several factors, such as solar radiation and ambient temperature, are negative to cooling efficiency. Reducing solar radiation may help to promote cooling efficiency, but as discussed above it will still reduce electricity generation as less solar energy will be received by solar cells. Meanwhile, increased ambient temperature would be the resistance to prevent the heat transferring from PV modules to environment, and decrease the cooling effect of PV modules. Some other factors have been proven as having negative impact on cooling efficiency, including channel length, channel depth and solar concentration ratio. Increased channel length may improve heat exchange area and then promote cooling effect, but also increase the retention time of heat in the channel and then prevent timely removal of heat. Meanwhile, raised solar concentration ratio contribute higher energy density of solar radiation and more heat accumulated on the surface of solar cells, leading to a lower the cooling efficiency, but these systems have harvested more heat or higher-grade thermal energy. In addition, some sub-methods, namely, water evaporative cooling, jet impingement cooling, heat pump and heat pipe, are also favorable solutions to enhance the rate of heat flow or supply a lower water temperature to take away the redundant heat. 


\begin{tabular}{|c|c|c|c|c|c|c|}
\hline $\begin{array}{c}\text { Cooling } \\
\text { technologies }\end{array}$ & Factors & $\begin{array}{l}\text { Cooling } \\
\text { efficiency }\end{array}$ & $\begin{array}{l}\text { Electrical } \\
\text { efficiency }\end{array}$ & $\begin{array}{c}\text { Electricity } \\
\text { yield }\end{array}$ & $\begin{array}{l}\text { Thermal } \\
\text { efficiency }\end{array}$ & Summary \\
\hline \multirow[t]{6}{*}{ Air } & Solar radiation & $x$ & $x$ & $\checkmark$ & $\checkmark$ & \\
\hline & Ambient temperature & $x$ & $x$ & $x$ & $\checkmark$ & The applicability of air fluids is good, but cooling effect is poor and \\
\hline & Wind speed & $\checkmark$ & $\checkmark$ & $\checkmark$ & $x$ & volume flow required is large. \\
\hline & Channel length & $x$ & $x$ & $x$ & $\checkmark$ & Air-cooling is mainly applied to natural cooling, dry agricultural \\
\hline & Channel depth & $x$ & $x$ & $x$ & $\checkmark$ & products, space heating and ventilation. \\
\hline & Air mass flow rate & $\checkmark$ & $\checkmark$ & $\checkmark$ & $\checkmark$ & \\
\hline \multirow[t]{9}{*}{ Water } & Solar radiation & $x$ & $x$ & $\checkmark$ & $\checkmark$ & \\
\hline & Ambient temperature & $x$ & $x$ & $x$ & $\checkmark$ & \\
\hline & Wind speed & $\checkmark$ & $\checkmark$ & $\checkmark$ & $x$ & Dhe water-fluid has higher specific heat capacity, higher heat transfer \\
\hline & Inlet water temperature & $\checkmark$ & $\checkmark$ & $\checkmark$ & $\checkmark$ & coefficient, better cooling effect, less required flow rate, but is prone to \\
\hline & Water mass flow rate & $\checkmark$ & $\checkmark$ & $\checkmark$ & $\checkmark$ & freezing in severe cold regions. \\
\hline & Water evaporative cooling & $\checkmark$ & $\checkmark$ & $\checkmark$ & $x$ & Water-cooling is mainly applied to domestic water heater, solar \\
\hline & Jet impingement cooling & $\checkmark$ & $\checkmark$ & $\checkmark$ & $\checkmark$ & refrigeration and low grade thermal power generation. \\
\hline & Heat pipe & $\checkmark$ & $\checkmark$ & $\checkmark$ & $\checkmark$ & \\
\hline & Heat pump & $\checkmark$ & $\checkmark$ & $\checkmark$ & $\checkmark$ & \\
\hline Nanofluids & Channel location & $\checkmark$ & O & O & $\checkmark$ & Nanofluids are widely used as coolants and optical filter, owing to their \\
\hline
\end{tabular}




\begin{tabular}{|c|c|c|c|c|c|c|}
\hline & Nanoparticle matter & $\checkmark$ & $\checkmark$ & $\checkmark$ & $\checkmark$ & high thermal conductivity and characteristic of spectrum absorption. \\
\hline & Nanoparticle size & O & O & O & $\checkmark$ & Solar concentration ratio has a critical impact on cooling efficiency, \\
\hline & Mass or volume fraction & $\checkmark$ & O & O & $\checkmark$ & electrical and thermal performance, but with high energy levels. \\
\hline & Solar concentration ratio & $x$ & $x$ & $\checkmark$ & $\checkmark$ & \\
\hline $\begin{array}{c}\text { Structural } \\
\text { configuration }\end{array}$ & Flow channels & O & O & O & $\checkmark$ & $\begin{array}{l}\text { Structural configuration enhances heat transfer and reduces cell } \\
\text { temperature. }\end{array}$ \\
\hline & Fins design & $\checkmark$ & $\checkmark$ & $\checkmark$ & $\checkmark$ & D Complex structural configuration lead to an increase in investment and \\
\hline & Filler & $\checkmark$ & $\checkmark$ & $\checkmark$ & $\checkmark$ & maintenance costs. \\
\hline PCMs & Fins attached & $\checkmark$ & $\checkmark$ & $\checkmark$ & $\checkmark$ & $\begin{array}{l}\text { Phase change material can store excess heat of the PV cell without } \\
\text { significantly increasing the temperature. }\end{array}$ \\
\hline
\end{tabular}

$\checkmark:$ The factor or sub-method has a positive effect; $x$ : The factor or sub-method has a negative effect; $O$ : Not discussed 


\section{Conclusions}

Photovoltaic modules are key sustainable devices achieving transformation of solar energy into electricity through photoelectric effect. During this transformation process, cell temperature has a critical impact the efficiency. To reduce cell temperature for better transformation efficiency, many useful cooling technologies have been developed. This paper, therefore, has reviewed the up-to-date development of these technologies and made appropriate comments and comparisons. Main findings from this study are listed as followings:

- Existing methods used for cooling PV modules have been classified into three classes in this study, namely, fluid medium cooling, optimizing structural configuration cooling and phase change materials cooling, according to the ways or principles of cooling.

- Air-based cooling systems have advantages like non-pollution, low-temperature usability and environment-friendly, but with limited thermal conductivity and specific heat. Water-based cooling systems achieve higher thermal conductivity and heat transfer coefficient, hence giving better cooling efficiency for PV modules, but not suitable for severe cold regions due to freezing at $0^{\circ} \mathrm{C}$. Nanofluids are burgeoning technologies for cooling PV modules because of their high thermal conductivity mixing with fins or nanoparticles. However, due to system complexity and energy consumption characteristics, active cooling technologies has not been widely used at present.

- Structural configuration is optimized to increase either disturbance or heat transfer area to boost

- PCMs can absorb excess heat of solar cells without significant increase of cell temperature due to heat removable from PV modules. Complex structural design, however, may lead to increased their large latent heat absorption or releasement when changing phase. Adding fins and nanoparticles can help to enhance PCMs' thermal conductivity, hence improving cooling efficiency.

- External environmental factors, including solar radiation, wind speed, relative humidity and ambient temperature, all have crucial influence on the efficiency of all cooling technologies. Some design related factors, including channel design, nanoparticles parameters and solar concentration 

modules.

Although most cooling technologies reviewed in this paper are matured, there are still problems need to be solved, such as the choice of cooling fluid and its usability for specific regions, the fouling accumulation and cleaning of enhanced heat exchangers with complex structures, the balance between cooling cost and net efficiency of PV modules, the cooling of circulating water in tropical areas and the freezing of circulating water in cold areas.

\section{Acknowledgements}

The authors gratefully acknowledge the funding support from the National Key R\&D Program of China (No. 2017YFC0702900).

\section{References}

[1] Aklin M., Bayer P., Harish S.P., Urpelainen J., Does basic energy access generate socioeconomic benefits? A field experiment with off-grid solar power in India. Science Advances, 2017, 3: e1602153. [2] Lovins A.B., A bright future. Science, 2015, 350: 169. with batteries depending on solar radiation, temperature and number of serial connected PV cells. Solar Energy, 2019, 183: 120-131.

540 [4] Wijeratne W.M.P.U., Yang R.J., Too E., Wakefield R., Design and development of distributed solar 541 PV systems: Do the current tools work? Sustainable Cities and Society, 2019, 45: 553-578.

542 [5] Lv Y., Si P., Rong X., Yan J., Feng Y., Zhu X., Determination of optimum tilt angle and orientation 543 for solar collectors based on effective solar heat collection. Applied Energy, 2018, 219: 11-19.

544 [6] Shafieian A., Khiadani M., Nosrati A., Strategies to improve the thermal performance of heat pipe solar collectors in solar systems: A review. Energy Conversion and Management, 2019, 183: 307-331. [7] Zervos A., Renewables 2018 - Global Status Report. Renewable Energy Policy Network for the 21st Century, 2018,

548 [8] Alonso García M.C., Balenzategui J.L., Estimation of photovoltaic module yearly temperature and performance based on Nominal Operation Cell Temperature calculations. Renewable Energy, 2004, 29: $550 \quad 1997-2010$.

551 [9] Beattie N.S., Moir R.S., Chacko C., Buffoni G., Roberts S.H., Pearsall N.M., Understanding the 552 effects of sand and dust accumulation on photovoltaic modules. Renewable Energy, 2012, 48: 448-452.

553 [10] Kazem A.A., Chaichan M.T., Kazem H.A., Dust effect on photovoltaic utilization in Iraq: Review 554 article. Renewable and Sustainable Energy Reviews, 2014, 37: 734-749.

555 [11] T I., cGrid-connected photovoltaic power systems: survey of inverter and related protection 556 equipments. International Energy Agency (IEA), 2002,

557 [12] Kalogirou S.A., Photovoltaic Systems Solar Energy Engineering : Processs and Systems, 558 Academic Press, 2009.

559 [13] Duffie J.A., Solar Engineering of Thermal Processes (Fourth Edition : Design of Photovoltaic 560 Systems. Wiley, 2013 
[14] Kalogirou S., Solar energy engineering: processes and systems: chapter 9. Academic Press, pp. 469-517, 2009.

[15] Yamaguchi T., Kawakami M., Kitano K., Nakagawa S., Tokoro T., Nakano T., Hayama K., Ohyama H., Data analysis on performance of PV system installed in south and north directions. 3rd World Conference onPhotovoltaic Energy Conversion, 2003. Proceedings of, 2003, pp. 2239-2242 Vol.3.

[16] Othman M.Y., Ibrahim A., Jin G.L., Ruslan M.H., Sopian K., Photovoltaic-thermal (PV/T) technology - The future energy technology. Renewable Energy, 2013, 49: 171-174.

[17] Preet S., Bhushan B., Mahajan T., Experimental investigation of water based photovoltaic/thermal (PV/T) system with and without phase change material (PCM). Solar Energy, 2017, 155: 1104-1120.

[18] Kern E.C., Russell M.C., Combined photovoltaic and thermal hybrid collector systems. IEEE Photovoltaic Specialists Conference, Washington DC, USA, 1978, pp. 1153-1157.

[19] Al-Waeli A.H.A., Chaichan M.T., Kazem H.A., Sopian K., Comparative study to use nano-(Al2O3, $\mathrm{CuO}$, and $\mathrm{SiC}$ ) with water to enhance photovoltaic thermal PV/T collectors. Energy Conversion and Management, 2017, 148: 963-973. spectrally selective absorbing nanofluids. Applied Energy, 2017, 193: 1-14.

[21] Rand BP, Genoe J, Heremans P, J P., Solar cells utilizing small Molecular weight organic semiconductors. Progress in Photovoltaics Research \& Applications, 2015, 15: 659-676. [22] Tyagi V.V., Rahim N.A.A., Rahim N.A., Selvaraj J.A.L., Progress in solar PV technology: Research and achievement. Renewable and Sustainable Energy Reviews, 2013, 20: 443-461. [23] Assoa Y.B., Sauzedde F., Boillot B., Boddaert S., Development of a building integrated solar photovoltaic/thermal hybrid drying system. Energy, 2017, 128: 755-767.

[24] Ahmed O.K., Hamada K.I., Salih A.M., Enhancement of the performance of Photovoltaic/Trombe wall system using the porous medium: Experimental and theoretical study. Energy, 2019, 171: 14-26. [25] Fellah A., Boukhchana Y., Ben Brahim A., Quasi-real performances of an irreversible solar absorption refrigeration cycle. International Journal of Refrigeration, 2019, 100: 21-26.

[26] Gourdo L., Fatnassi H., Tiskatine R., Wifaya A., Demrati H., Aharoune A., Bouirden L., Solar energy storing rock-bed to heat an agricultural greenhouse. Energy, 2019, 169: 206-212.

[27] Hazami M., Kooli S., Naili N., Farhat A., Long-term performances prediction of an evacuated tube solar water heating system used for single-family households under typical Nord-African climate (Tunisia). Solar Energy, 2013, 94: 283-298.

[28] Kalogirou S.A., Mathioulakis E., Belessiotis V., Artificial neural networks for the performance prediction of large solar systems. Renewable Energy, 2014, 63: 90-97.

[29] Karthick K., Suresh S., Joy G.C., Dhanuskodi R., Experimental investigation of solar reversible power generation in Thermoelectric Generator (TEG) using thermal energy storage. Energy for Sustainable Development, 2019, 48: 107-114.

[30] Jafari Mosleh H., Hakkaki-Fard A., DaqiqShirazi M., A year-round dynamic simulation of a solar combined, ejector cooling, heating and power generation system. Applied Thermal Engineering, 2019, 153: 1-14.

602 [31] Good C., Andresen I., Hestnes A.G., Solar energy for net zero energy buildings - A comparison between solar thermal, PV and photovoltaic-thermal (PV/T) systems. Solar Energy, 2015, 122: 986-996.

604 [32] Kamel R.S., Fung A.S., Modeling, simulation and feasibility analysis of residential 
BIPV/T+ASHP system in cold climate—Canada. Energy and Buildings, 2014, 82: 758-770.

[33] Gholampour M., Ameri M., Energy and exergy analyses of Photovoltaic/Thermal flat transpired collectors: Experimental and theoretical study. Applied Energy, 2016, 164: 837-856.

[34] Hussain F., Othman M.Y.H., Yatim B., Ruslan H., Sopian K., Anuar Z., Khairuddin S., An improved design of photovoltaic/thermal solar collector. Solar Energy, 2015, 122: 885-891.

[35] Solanki S.C., Dubey S., Tiwari A., Indoor simulation and testing of photovoltaic thermal (PV/T) air collectors. Applied Energy, 2009, 86: 2421-2428.

[36] Mojumder J.C., Chong W.T., Ong H.C., Leong K.Y., Abdullah Al M., An experimental investigation on performance analysis of air type photovoltaic thermal collector system integrated with cooling fins design. Energy and Buildings, 2016, 130: 272-285.

[37] Teo H.G., Lee P.S., Hawlader M.N.A., An active cooling system for photovoltaic modules. Applied Energy, 2012, 90: 309-315.

[38] Sohel M.I., Ma Z., Cooper P., Adams J., Scott R., A theoretical investigation of a solar photovoltaic thermal system integrated with phase change materials. 2013,

[39] Koech R., Ondieki H., K Tonui J., K Rotich S., A Steady State Thermal Model For Photovoltaic/Thermal (PV/T) System Under Various Conditions. 2012

[40] Sanusi Y.K., R Fajinmi G., B Babatunde E., Effects of Ambient Temperature on the Performance of a Photovoltaic Solar System in a Tropical Area. 2011

[41] Adeli M.M., Sobhnamayan F., Farahat S., Alavi M.A., Sarhaddi F., Experimental Performance Evaluation of a Photovoltaic Thermal (PV/T) Air Collector and Its Optimization. Strojniski Vestnik, 2012, 58: 309-318.

[42] Tonui J.K., Tripanagnostopoulos Y., Air-cooled PV/T solar collectors with low cost performance improvements. Solar Energy, 2007, 81: 498-511.

[43] Garg H.P., Adhikari R.S., Conventional hybrid photovoltaic/thermal (PV/T) air heating collectors: steady-state simulation. Renewable Energy, 1997, 11: 363-385.

[44] Tiwari A., Sodha M.S., Parametric study of various configurations of hybrid PV/thermal air collector: Experimental validation of theoretical model. Solar Energy Materials and Solar Cells, 2007, 91: 17-28.

[45] Yang T., Athienitis A.K., A study of design options for a building integrated photovoltaic/thermal (BIPV/T) system with glazed air collector and multiple inlets. Solar Energy, 2014, 104: 82-92.

[46] Abdul Hamid S., Yusof Othman M., Sopian K., Zaidi S.H., An overview of photovoltaic thermal combination (PV/T combi) technology. Renewable and Sustainable Energy Reviews, 2014, 38: 212-222.

[47] Al-Waeli A.H.A., Sopian K., Kazem H.A., Chaichan M.T., Photovoltaic/Thermal (PV/T) systems: Status and future prospects. Renewable and Sustainable Energy Reviews, 2017, 77: 109-130.

[48] Singh I., Singh D., Singh M., Thermal Modeling and Performance Evaluation of Photovoltaic Thermal (PV/T) Systems: A Parametric Study. International Journal of Green Energy, 2019, 16: 483-489.

[49] Heng Z., Haowen L., Haiping C., Xinxin G., Kai L., Pengbo Y., Research on the Performance of Flat-Box Photovoltaic/Thermal Collector With Cooling Channels. Journal of Solar Energy Engineering, 2017, 140: 021002-021002-10.

[50] Vittorini D., Castellucci N., Cipollone R., Heat recovery potential and electrical performances in-field investigation on a hybrid PVT module. Applied Energy, 2017, 205: 44-56.

[51] Salari A., Hakkaki-Fard A., A numerical study of dust deposition effects on photovoltaic modules 
and photovoltaic-thermal systems. Renewable Energy, 2019, 135: 437-449.

[52] Fudholi A., Sopian K., Yazdi M.H., Ruslan M.H., Ibrahim A., Kazem H.A., Performance analysis of photovoltaic thermal (PVT) water collectors. Energy Conversion and Management, 2014, 78: 641-651.

[53] Shi Q., Lv J., Guo C., Zheng B., Experimental and simulation analysis of a PV/T system under the pattern of natural circulation. Applied Thermal Engineering, 2017, 121: 828-837.

[54] Krauter S., Increased electrical yield via water flow over the front of photovoltaic panels. Solar Energy Materials and Solar Cells, 2004, 82: 131-137.

[55] Abdolzadeh M., Ameri M., Improving the effectiveness of a photovoltaic water pumping system by spraying water over the front of photovoltaic cells. Renewable Energy, 2009, 34: 91-96.

[56] Fang G., Hu H., Liu X., Experimental investigation on the photovoltaic-thermal solar heat pump air-conditioning system on water-heating mode. Experimental Thermal and Fluid Science, 2010, 34: 736-743.

[57] Moradgholi M., Nowee S.M., Abrishamchi I., Application of heat pipe in an experimental investigation on a novel photovoltaic/thermal (PV/T) system. Solar Energy, 2014, 107: 82-88.

[58] Chen H., Zhang L., Jie P., Xiong Y., Xu P., Zhai H., Performance study of heat-pipe solar photovoltaic/thermal heat pump system. Applied Energy, 2017, 190: 960-980.

[59] Bigorajski J., Chwieduk D., Analysis of a micro photovoltaic/thermal - PV/T system operation in moderate climate. Renewable Energy, 2019, 137: 127-136.

[60] Wu S.-Y., Chen C., Xiao L., Heat transfer characteristics and performance evaluation of water-cooled PV/T system with cooling channel above PV panel. Renewable Energy, 2018, 125: 936-946.

[61] İlayda Koç, Başaran K., PV/T Tabanlı Bir Sistemde MATLAB/Simulink Kullanılarak Yapılan Performans Analizi. Journal of Polytechnic, 2019, 22: 229-236.

[62] Lanzafame R., Nachtmann S., Rosa-Clot M., Rosa-Clot P., Scandura P.F., Taddei S., Tina G.M., Field Experience With Performances Evaluation of a Single-Crystalline Photovoltaic Panel in an Underwater Environment. IEEE Transactions on Industrial Electronics, 2010, 57: 2492-2498.

[63] Gaur A., Tiwari G.N., Performance of a-Si thin film PV modules with and without water flow: An experimental validation. Applied Energy, 2014, 128: 184-191.

[64] Jordehi A.R., Parameter estimation of solar photovoltaic (PV) cells: A review. Renewable and Sustainable Energy Reviews, 2016, 61: 354-371.

[65] Awad M., Radwan A., Abdelrehim O., Emam M., N. Shmroukh A., Ahmed M., Performance evaluation of concentrator photovoltaic systems integrated with a new jet impingement-microchannel heat sink and heat spreader. Solar Energy, 2020, 199: 852-863.

[66] Radwan A., Ahmed M., The influence of microchannel heat sink configurations on the performance of low concentrator photovoltaic systems. Applied Energy, 2017, 206: 594-611.

[67] Royne A., Dey C.J., Mills D.R., Cooling of photovoltaic cells under concentrated illumination: a critical review. Solar Energy Materials and Solar Cells, 2005, 86: 451-483.

[68] Hasan H.A., Sopian K., Fudholi A., Photovoltaic thermal solar water collector designed with a jet collision system. Energy, 2018, 161: 412-424.

[69] Bahaidarah H.M.S., Experimental performance evaluation and modeling of jet impingement cooling for thermal management of photovoltaics. Solar Energy, 2016, 135: 605-617.

[70] Dannemand M., Perers B., Furbo S., Performance of a demonstration solar PVT assisted heat pump system with cold buffer storage and domestic hot water storage tanks. Energy and Buildings, 
2019, 188-189: 46-57.

[71] Bellos E., Tzivanidis C., Multi-objective optimization of a solar assisted heat pump-driven by hybrid PV. Applied Thermal Engineering, 2019, 149: 528-535.

[72] Li H., Sun Y., Operational performance study on a photovoltaic loop heat pipe/solar assisted heat pump water heating system. Energy and Buildings, 2018, 158: 861-872.

[73] Cai J., Ji J., Wang Y., Zhou F., Yu B., A novel PV/T-air dual source heat pump water heater system: Dynamic simulation and performance characterization. Energy Conversion and Management, 2017, 148: 635-645.

[74] Wu S.-Y., Zhang Q.-L., Xiao L., Guo F.-H., A heat pipe photovoltaic/thermal (PV/T) hybrid system and its performance evaluation. Energy and Buildings, 2011, 43: 3558-3567.

[75] Gang P., Huide F., Jie J., Tin-tai C., Tao Z., Annual analysis of heat pipe PV/T systems for domestic hot water and electricity production. Energy Conversion and Management, 2012, 56: 8-21.

[76] Qu M., Chen J., Nie L., Li F., Yu Q., Wang T., Experimental study on the operating characteristics of a novel photovoltaic/thermal integrated dual-source heat pump water heating system. Applied Thermal Engineering, 2016, 94: 819-826.

[77] Wang G., Zhao Y., Quan Z., Tong J., Application of a multi-function solar-heat pump system in residential buildings. Applied Thermal Engineering, 2018, 130: 922-937.

[78] Sardarabadi M., Passandideh-Fard M., Zeinali Heris S., Experimental investigation of the effects of silica/water nanofluid on PV/T (photovoltaic thermal units). Energy, 2014, 66: 264-272.

[79] Hassani S., Taylor R.A., Mekhilef S., Saidur R., A cascade nanofluid-based PV/T system with optimized optical and thermal properties. Energy, 2016, 112: 963-975.

[80] An W., Wu J., Zhu T., Zhu Q., Experimental investigation of a concentrating PV/T collector with Cu9S5 nanofluid spectral splitting filter. Applied Energy, 2016, 184: 197-206.

[81] Zhao X., Li Y., Feng S., Chen X., Li C., Wang Y., Beam splitting characteristics of two-dimensional photonic crystals based on surface modulation. Optics Communications, 2019, 439: 193-200.

[82] Qu W., Hong H., Jin H., A spectral splitting solar concentrator for cascading solar energy utilization by integrating photovoltaics and solar thermal fuel. Applied Energy, 2019, 248: 162-173.

[83] Crisostomo F., Taylor R.A., Surjadi D., Mojiri A., Rosengarten G., Hawkes E.R., Spectral splitting strategy and optical model for the development of a concentrating hybrid PV/T collector. Applied Energy, 2015, 141: 238-246.

[84] Karami N., Rahimi M., Heat transfer enhancement in a hybrid microchannel-photovoltaic cell using Boehmite nanofluid. International Communications in Heat and Mass Transfer, 2014, 55: 45-52.

[85] Zhao J., Song Y., Lam W.-H., Liu W., Liu Y., Zhang Y., Wang D., Solar radiation transfer and performance analysis of an optimum photovoltaic/thermal system. Energy Conversion and Management, 2011, 52: 1343-1353.

[86] He Q., Wang S., Zeng S., Zheng Z., Experimental investigation on photothermal properties of nanofluids for direct absorption solar thermal energy systems. Energy Conversion and Management, 2013, 73: 150-157.

[87] Du M., Tang G.H., Optical property of nanofluids with particle agglomeration. Solar Energy, 2015, 122: 864-872.

[88] Han X., Xue D., Zheng J., Alelyani S.M., Chen X., Spectral characterization of spectrally selective liquid absorption filters and exploring their effects on concentrator solar cells. Renewable Energy, 2019, 131: 938-945. 
[89] Day J., Senthilarasu S., Mallick T.K., Improving spectral modification for applications in solar cells: A review. Renewable Energy, 2019, 132: 186-205.

[90] Otanicar T.P., Taylor R.A., Telang C., Photovoltaic/thermal system performance utilizing thin film and nanoparticle dispersion based optical filters. Journal of Renewable and Sustainable Energy, 2013, 5: 033124.

[91] Cui Y., Zhu Q., Study of Photovoltaic/Thermal Systems with MgO-Water Nanofluids Flowing over Silicon Solar Cells. Asia-pacific Power \& Energy Engineering Conference, 2012,

[92] Rejeb O., Sardarabadi M., Ménézo C., Passandideh-Fard M., Dhaou M.H., Jemni A., Numerical and model validation of uncovered nanofluid sheet and tube type photovoltaic thermal solar system. Energy Conversion and Management, 2016, 110: 367-377.

[93] Khanjari Y., Pourfayaz F., Kasaeian A.B., Numerical investigation on using of nanofluid in a water-cooled photovoltaic thermal system. Energy Conversion and Management, 2016, 122: 263-278.

[94] Sardarabadi M., Passandideh-Fard M., Experimental and numerical study of metal-oxides/water nanofluids as coolant in photovoltaic thermal systems (PVT). Solar Energy Materials and Solar Cells, 2016, 157: 533-542.

[95] Hussein H., Hussein Numan A., Abdulmunem A., Indoor Investigation for Improving the Hybrid Photovoltaic IThermal System Performance Using Nanofluid (AL2O3-Water). Engineering and Technology Journal, 2015, 33: 889-901.

[96] Manikandan S., Rajan K.S., Sand-propylene glycol-water nanofluids for improved solar energy collection. Energy, 2016, 113: 917-929.

[97] Khanafer K., Vafai K., A review on the applications of nanofluids in solar energy field. Renewable Energy, 2018, 123: 398-406.

[98] Abdullah A.A., Althobaiti S.A., Lindsay K.A., Marangoni convection in water-alumina nanofluids: Dependence on the nanoparticle size. European Journal of Mechanics - B/Fluids, 2018, 67: 259-268.

[99] Wang R., Qian S., Zhang Z., Investigation of the aggregation morphology of nanoparticle on the thermal conductivity of nanofluid by molecular dynamics simulations. International Journal of Heat and Mass Transfer, 2018, 127: 1138-1146.

[100] Hjerrild N.E., Mesgari S., Crisostomo F., Scott J.A., Amal R., Taylor R.A., Hybrid PV/T enhancement using selectively absorbing $\mathrm{Ag}-\mathrm{SiO} 2 /$ carbon nanofluids. Solar Energy Materials and Solar Cells, 2016, 147: 281-287.

[101] Radwan A., Ahmed M., Ookawara S., Performance enhancement of concentrated photovoltaic systems using a microchannel heat sink with nanofluids. Energy Conversion and Management, 2016, 119: 289-303.

[102] Hassani S., Saidur R., Mekhilef S., Taylor R.A., Environmental and exergy benefit of nanofluid-based hybrid PV/T systems. Energy Conversion and Management, 2016, 123: 431-444.

[103] Zondag H.A., de Vries D.W., van Helden W.G.J., van Zolingen R.J.C., van Steenhoven A.A., The yield of different combined PV-thermal collector designs. Solar Energy, 2003, 74: 253-269.

[104] Amori K.E., Abd-AlRaheem M.A., Field study of various air based photovoltaic/thermal hybrid solar collectors. Renewable Energy, 2014, 63: 402-414.

[105] Hou L., Quan Z., Zhao Y., Wang L., Wang G., An experimental and simulative study on a novel photovoltaic-thermal collector with micro heat pipe array (MHPA-PV/T). Energy and Buildings, 2016, 124: 60-69.

[106] Ahmed O.K., Mohammed Z.A., Influence of porous media on the performance of hybrid PV/Thermal collector. Renewable Energy, 2017, 112: 378-387. 
[107] Ji J., Lu J.-P., Chow T.-T., He W., Pei G., A sensitivity study of a hybrid photovoltaic/thermal water-heating system with natural circulation. Applied Energy, 2007, 84: 222-237.

[108] Robles-Ocampo B., Ruíz-Vasquez E., Canseco-Sánchez H., Cornejo-Meza R.C., Trápaga-Martínez G., García-Rodriguez F.J., González-Hernández J., Vorobiev Y.V., Photovoltaic/thermal solar hybrid system with bifacial PV module and transparent plane collector. Solar Energy Materials and Solar Cells, 2007, 91: 1966-1971.

[109] Touafek K., Haddadi M., Malek A., Modeling and Experimental Validation of a New Hybrid Photovoltaic Thermal Collector. IEEE Transactions on Energy Conversion, 2011, 26: 176-183.

[110] Rahimi M., Valeh-e-Sheyda P., Parsamoghadam M.A., Masahi M.M., Alsairafi A.A., Design of a self-adjusted jet impingement system for cooling of photovoltaic cells. Energy Conversion and Management, 2014, 83: 48-57.

[111] Singh S., Agrawal S., Avasthi D.V., Design, modeling and performance analysis of dual channel semitransparent photovoltaic thermal hybrid module in the cold environment. Energy Conversion and Management, 2016, 114: 241-250.

[112] Ooshaksaraei P., Sopian K., Zaidi S.H., Zulkifli R., Performance of four air-based photovoltaic thermal collectors configurations with bifacial solar cells. Renewable Energy, 2017, 102: 279-293.

[113] Goh Li Jin, Adnan Ibrahim, Yee Kim Chean, Roonak Daghigh, Hafidz Ruslan, Sohif Mat, Mohd. Yusof Othman, Sopian K., Evaluation of Single-Pass Photovoltaic-Thermal Air Collector with Rectangle Tunnel Absorber. American Journal of Applied Sciences, 2010, 7: 277-282.

[114] Charalambous P.G., Kalogirou S.A., Maidment G.G., Yiakoumetti K., Optimization of the photovoltaic thermal (PV/T) collector absorber. Solar Energy, 2011, 85: 871-880.

[115] Dubeya S., A.O.Taybc A., Testing of two different types of photovoltaic-thermal (PVT) modules with heat flow pattern under tropical climatic conditions. Energy for Sustainable Development, 2013, 17: 1-12.

[116] Yousef B., Adam N., Sopian K., Zaharim A., Alghoul M., Analysis of single and double passes with and without porous media for V-groove absorber. 2007

[117] Xu P., Zhang X., Shen J., Zhao X., He W., Li D., Parallel experimental study of a novel super-thin thermal absorber based photovoltaic/thermal (PV/T) system against conventional photovoltaic (PV) system. Energy Reports, 2015, 1: 30-35.

[118] Dhiman P., Thakur N.S., Kumar A., Singh S., An analytical model to predict the thermal performance of a novel parallel flow packed bed solar air heater. Applied Energy, 2011, 88: 2157-2167. [119] Huo Y., Lv J., Li X., Fang L., Ma X., Shi Q., Experimental study on the tube plate PV/T system with iron filings filled. Solar Energy, 2019, 185: 189-198.

[120] Günther E., Hiebler S., Mehling H., Redlich R., Enthalpy of Phase Change Materials as a Function of Temperature: Required Accuracy and Suitable Measurement Methods. International Journal of Thermophysics, 2009, 30: 1257-1269.

[121] Cabeza L.F., Castell A., Barreneche C., de Gracia A., Fernández A.I., Materials used as PCM in thermal energy storage in buildings: A review. Renewable and Sustainable Energy Reviews, 2011, 15: 1675-1695.

[122] Hasan A., McCormack S.J., Huang M.J., Norton B., Evaluation of phase change materials for thermal regulation enhancement of building integrated photovoltaics. Solar Energy, 2010, 84: 1601-1612.

[123] Farid M.M., Khudhair A.M., Razack S.A.K., Al-Hallaj S., A review on phase change energy storage: materials and applications. Energy Conversion and Management, 2004, 45: 1597-1615. 
[124] Browne M.C., Norton B., McCormack S.J., Heat retention of a photovoltaic/thermal collector with PCM. Solar Energy, 2016, 133: 533-548.

[125] Zalba B., Marín J.M., Cabeza L.F., Mehling H., Review on thermal energy storage with phase change: materials, heat transfer analysis and applications. Applied Thermal Engineering, 2003, 23 : 251-283.

[126] Su D., Jia Y., Lin Y., Fang G., Maximizing the energy output of a photovoltaic-thermal solar collector incorporating phase change materials. Energy and Buildings, 2017, 153: 382-391.

[127] Malvi C.S., Dixon-Hardy D.W., Crook R., Energy balance model of combined photovoltaic solar-thermal system incorporating phase change material. Solar Energy, 2011, 85: 1440-1446.

[128] Ling H., Chen C., Guan Y., Wei S., Chen Z., Li N., Active heat storage characteristics of active-passive triple wall with phase change material. Solar Energy, 2014, 110: 276-285.

[129] Su D., Jia Y., Alva G., Liu L., Fang G., Comparative analyses on dynamic performances of photovoltaic-thermal solar collectors integrated with phase change materials. Energy Conversion and Management, 2017, 131: 79-89.

[130] Nazir H., Batool M., Bolivar Osorio F.J., Isaza-Ruiz M., Xu X., Vignarooban K., Phelan P., Inamuddin, Kannan A.M., Recent developments in phase change materials for energy storage applications: A review. International Journal of Heat and Mass Transfer, 2019, 129: 491-523.

[131] Qiu L., Zhu N., Feng Y., Michaelides E.E., Żyła G., Jing D., Zhang X., Norris P.M., Markides C.N., Mahian O., A review of recent advances in thermophysical properties at the nanoscale: From solid state to colloids. Physics Reports, 2020, 843: 1-81.

[132] Qiu L., Ouyang Y., Feng Y., Zhang X., Review on micro/nano phase change materials for solar thermal applications. Renewable Energy, 2019, 140: 513-538.

[133] Abdelrazik A.S., Al-Sulaiman F.A., Saidur R., Ben-Mansour R., A review on recent development for the design and packaging of hybrid photovoltaic/thermal (PV/T) solar systems. Renewable and Sustainable Energy Reviews, 2018, 95: 110-129.

[134] Lu W., Liu Z., Flor J.-F., Wu Y., Yang M., Investigation on designed fins-enhanced phase change materials system for thermal management of a novel building integrated concentrating PV. Applied Energy, 2018, 225: 696-709.

[135] Huang M.J., Eames P.C., Norton B., Hewitt N.J., Natural convection in an internally finned phase change material heat sink for the thermal management of photovoltaics. Solar Energy Materials and Solar Cells, 2011, 95: 1598-1603.

[136] Atkin P., Farid M.M., Improving the efficiency of photovoltaic cells using PCM infused graphite and aluminium fins. Solar Energy, 2015, 114: 217-228.

[137] Khanna S., Newar S., Sharma V., Reddy K.S., Mallick T.K., Optimization of fins fitted phase change material equipped solar photovoltaic under various working circumstances. Energy Conversion and Management, 2019, 180: 1185-1195.

[138] R.K. Sharma , Ganesan P., Solidification of Nano-Enhanced Phase Change Materials (NEPCM) in a Trapezoidal Cavity: A CFD Study. Universal Journal of Mechanical Engineering, 2014, 2: 187-192. [139] Wu S., Zhu D., Zhang X., Huang J., Preparation and Melting/Freezing Characteristics of Cu/Paraffin Nanofluid as Phase-Change Material (PCM). Energy \& Fuels, 2010, 24: 1894-1898.

[140] Al-Waeli A.H.A., Sopian K., Kazem H.A., Yousif J.H., Chaichan M.T., Ibrahim A., Mat S., Ruslan M.H., Comparison of prediction methods of PV/T nanofluid and nano-PCM system using a measured dataset and artificial neural network. Solar Energy, 2018, 162: 378-396.

[141] Shin D., Banerjee D., Enhanced Specific Heat of Silica Nanofluid. Journal of Heat Transfer, 2010, 

enhancement of photovoltaic cells by changing configuration and using PCM (RT35HC) with nanoparticles Al2O3. Solar Energy, 2019, 177: 665-671.

[143] Bondareva N.S., Buonomo B., Manca O., Sheremet M.A., Heat transfer inside cooling system based on phase change material with alumina nanoparticles. Applied Thermal Engineering, 2018, 144: 972-981.

[144] Khodadadi J.M., Hosseinizadeh S.F., Nanoparticle-enhanced phase change materials (NEPCM) with great potential for improved thermal energy storage. International Communications in Heat and Mass Transfer, 2007, 34: 534-543.

[145] Colla L., Fedele L., Mancin S., Danza L., Manca O., Nano-PCMs for enhanced energy storage and passive cooling applications. Applied Thermal Engineering, 2017, 110: 584-589.

[146] Qiu Z., Zhao X., Li P., Zhang X., Ali S., Tan J., Theoretical investigation of the energy performance of a novel MPCM (Microencapsulated Phase Change Material) slurry based PV/T module. Energy, 2015, 87: 686-698.

[147] Siahkamari L., Rahimi M., Azimi N., Banibayat M., Experimental investigation on using a novel phase change material (PCM) in micro structure photovoltaic cooling system. International Communications in Heat and Mass Transfer, 2019, 100: 60-66.

[148] Han P., Zheng X.-H., Hou W.-S., Qiu L., Tang D.-W., Study on heat-storage and release characteristics of multi-cavity-structured phase-change microcapsules. Phase Transitions, 2015, 88: 704-715.

[149] Maiti S., Banerjee S., Vyas K., Patel P., Ghosh P.K., Self regulation of photovoltaic module temperature in V-trough using a metal-wax composite phase change matrix. Solar Energy, 2011, 85: 1805-1816.

[150] Ali H.M., Recent advancements in PV cooling and efficiency enhancement integrating phase change materials based systems - A comprehensive review. Solar Energy, 2020, 197: 163-198.

[151] Daghigh R., Ibrahim A., Jin G.L., Ruslan M.H., Sopian K., Predicting the performance of amorphous and crystalline silicon based photovoltaic solar thermal collectors. Energy Conversion and Management, 2011, 52: 1741-1747.

[152] Assoa Y.B., Menezo C., Fraisse G., Yezou R., Brau J., Study of a new concept of photovoltaic-thermal hybrid collector. Solar Energy, 2007, 81: 1132-1143.

[153] Taylor R.A., Otanicar T., Rosengarten G., Nanofluid-based optical filter optimization for PV/T systems. Light: Science \&Amp; Applications, 2012, 1: e34.

[154] Hjerrild N.E., Taylor R.A., Boosting solar energy conversion with nanofluids. Physics Today, 2017, 70: 40-45.

[155] Shen J., Cao N., Accurate inversion of tropospheric aerosol extinction coefficient profile by Mie-Raman lidar. Optik, 2019, 184: 153-164.

[156] Zhao Q., Yao W., Zhang C., Wang X., Wang Y., Study on the influence of fog and haze on solar radiation based on scattering-weakening effect. Renewable Energy, 2019, 134: 178-185.

[157] Park H., Lee S.J., Jung S.Y., Effect of nanofluid formation methods on behaviors of boiling bubbles. International Journal of Heat and Mass Transfer, 2019, 135: 1312-1318.

[158] Gao R., Shen C., Wang X., Yao Y., Experimental study on the sticking probability and deposit bond strength of fouling in enhanced tubes. International Communications in Heat and Mass Transfer, 2019, 103: 17-23. 
913 [159] Shen C., Gao R., Wang X., Yao Y., Investigation on fouling of enhanced tubes used in a cooling

914 tower water system based on a long-term test. International Journal of Refrigeration, 2019, 104: 9-18.

915 [160] Shen C., Wang Y., Tang Z., Yao Y., Huang Y., Wang X., Experimental study on the interaction

916 between particulate fouling and precipitation fouling in the fouling process on heat transfer tubes.

917 International Journal of Heat and Mass Transfer, 2019, 138: 1238-1250. 